Review

\title{
Performance of structural glass facades under extreme loads - Design methods, existing research, current issues and trends
}

\author{
Chiara Bedon $^{\mathrm{a}, *}$, Xihong Zhang ${ }^{\mathrm{b}}$, Filipe Santos ${ }^{\mathrm{c}}$, Dániel Honfi ${ }^{\mathrm{d}}$, Marcin Kozłowski ${ }^{\mathrm{e}, \mathrm{f}}$, Michel Arrigoni ${ }^{\mathrm{g}}$, \\ Lucia Figuli $^{\mathrm{h}}$, David Lange ${ }^{\mathrm{d}}$ \\ a Department of Engineering and Architecture, University of Trieste, Trieste, Italy \\ ${ }^{\mathrm{b}}$ Centre for Infrastructure Monitoring and Protection, School of Civil and Mechanical Engineering, Curtin University, Bentley, Australia

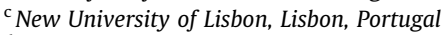 \\ ${ }^{\mathrm{d}}$ RISE Research Institutes of Sweden, Borås, Sweden \\ e Silesian University of Technology, Gliwice, Poland \\ ${ }^{\mathrm{f}}$ LTH, Lund University, Lund, Sweden \\ ${ }^{\mathrm{g}}$ ENSTA Bretagne, Brest, France \\ ${ }^{\mathrm{h}}$ University of Žilina, Žilina, Slovakia
}

\section{H I G H L I G H T S}

- Glass in windows and facades is largely used, for many practical reasons.

- Material intrinsic features make glass facades one of the most vulnerable component of buildings.

- Fail-safe design requirements are mandatory, especially under extreme loads.

- Design methods for some key extreme design actions are analysed.

\section{A R T I C L E I N F O}

\section{Article history:}

Received 22 August 2017

Received in revised form 12 December 2017 Accepted 22 December 2017

\section{Keywords:}

Structural glass

Glass facades

Extreme loads

Design standards and regulations

Vulnerability

Mitigation and protection
G R A P H I C A L A B S T R A C T

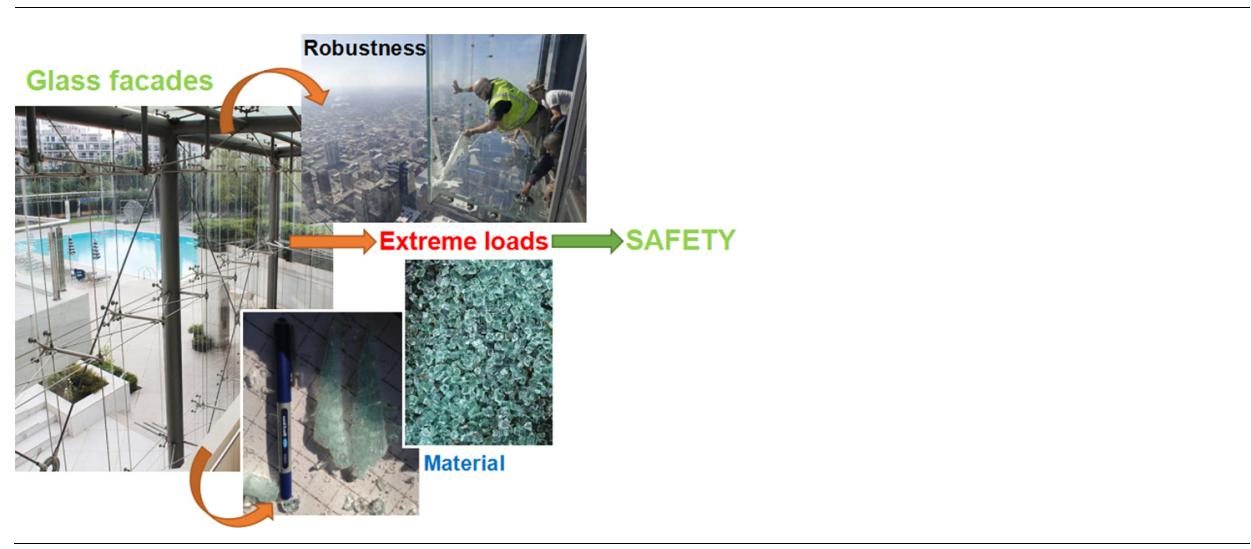

\section{A B S T R A C T}

Glass has been overwhelmingly used for windows and facades in modern constructions, for many practical reasons, including thermal, energy, light and aesthetics. Nevertheless, due to the relatively low tensile strength and mostly brittle behaviour of glass, compared to other traditional materials, as well as to a multitude of interacting structural and non-structural components, windows/facades are one of the most fragile and vulnerable components of buildings, being representative of the physical line of separation between interior and exterior spaces. As such, multidisciplinary approaches, as well as specific fail-safe design criteria and analysis methods are required, especially under extreme loading conditions, so that casualties and injuries in the event of failure could be avoided and appropriate safety levels could be guaranteed. In this context, this paper presents a review of the state of art on analysis and design methods in use for glass facades, with careful consideration for extreme loading configurations, including natural events, such as seismic events, extreme wind or other climatic exposures, and man-made threats, i.e. blast loads and fire. Major results of available experimental outcomes, current issues and trends are also reported, summarising still open challenges.

(c) 2017 Elsevier Ltd. All rights reserved.

\footnotetext{
* Corresponding author at: Department of Engineering and Architecture, University of Trieste, Piazzale Europa 1, 34127 Trieste, Italy.

E-mail address: chiara.bedon@dia.units.it (C. Bedon).
} 


\section{Contents}

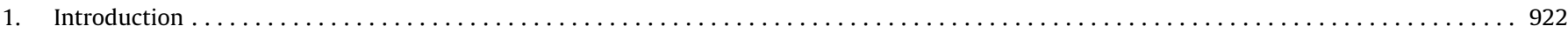

2. Glass in buildings. . . . . . . . . .

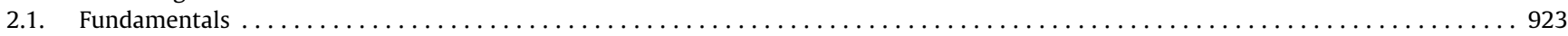

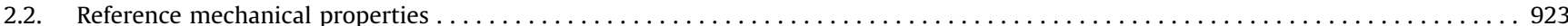

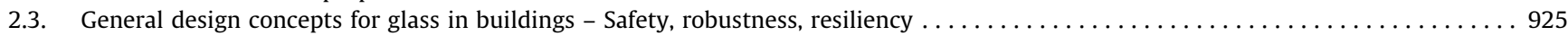

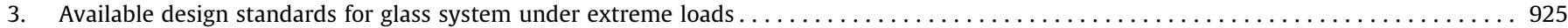

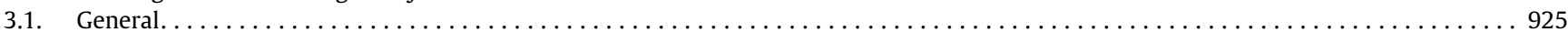

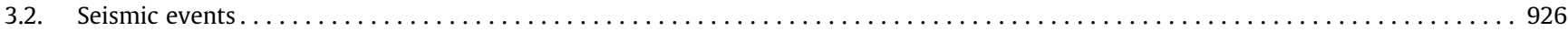

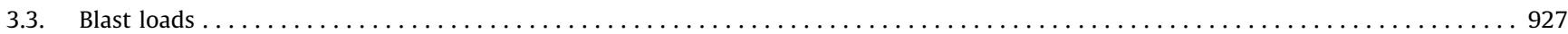

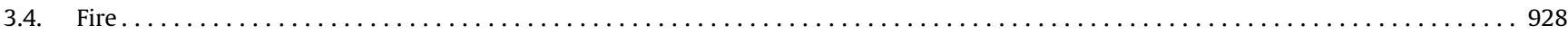

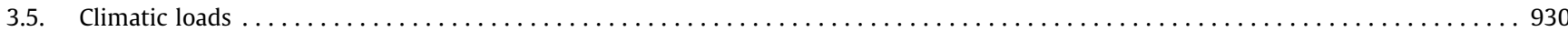

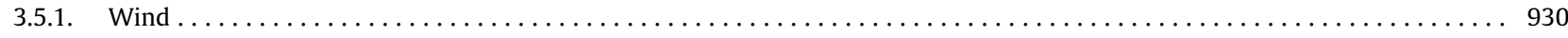

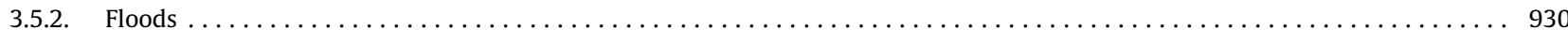

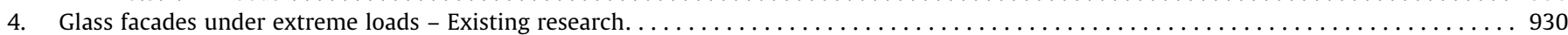

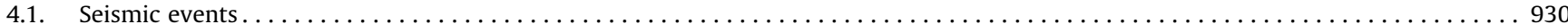

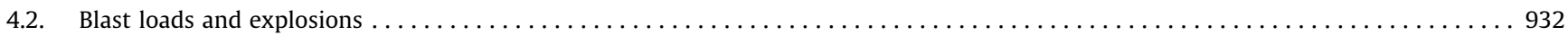

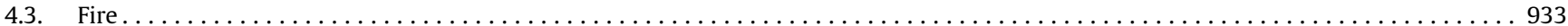

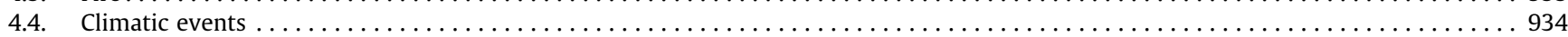

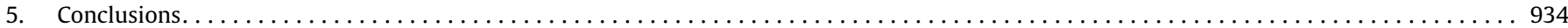

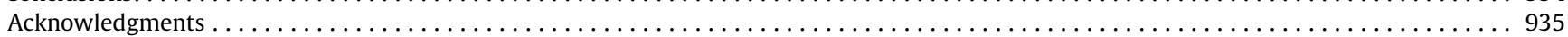

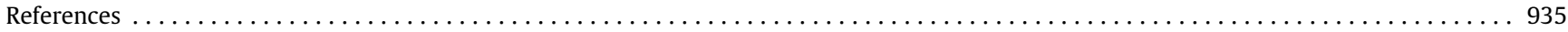

\section{Introduction}

The industrialized use of glass as a load bearing material for construction is a relatively recent solution, compared to traditional and consolidated solutions such as timber, steel, concrete or masonry. On one hand, positive arguments related to the thermal, energy, light and aesthetic performance of glass lead to continuously increasing applications including an evolution towards geometrically complex solutions, see Fig. 1 . On the other hand, due to the relatively low tensile strength and brittle behavior of glass as a material in load bearing applications and as a result of a need to address large deformations, glazing windows and facades repre- sent a highly fragile and vulnerable component for buildings. This is true especially when extreme loading conditions are expected at the design stage, or could even occur over the lifetime of a given structural system, where glass envelopes provide the physical line of separation from the exterior. As a general rule, multidisciplinary approaches and specific fail-safe design criteria, including advanced analysis methods able to take into account the intrinsic properties of glass are required, so that casualties and injuries can be avoided in the event of failure and appropriate safety levels can be guaranteed (i.e. [1,2]).

The current review paper, in this context, aims to present the state of the art of analysis and design methods in use for glass

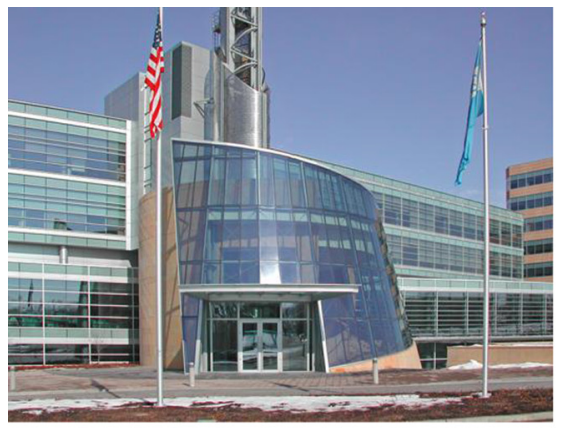

(a)

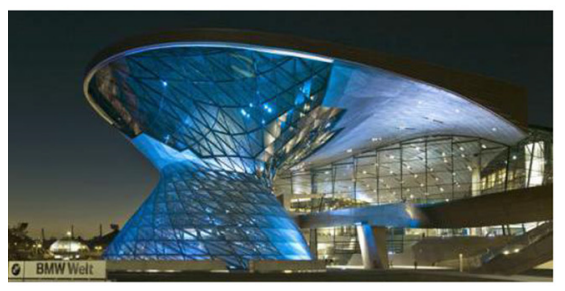

(b)

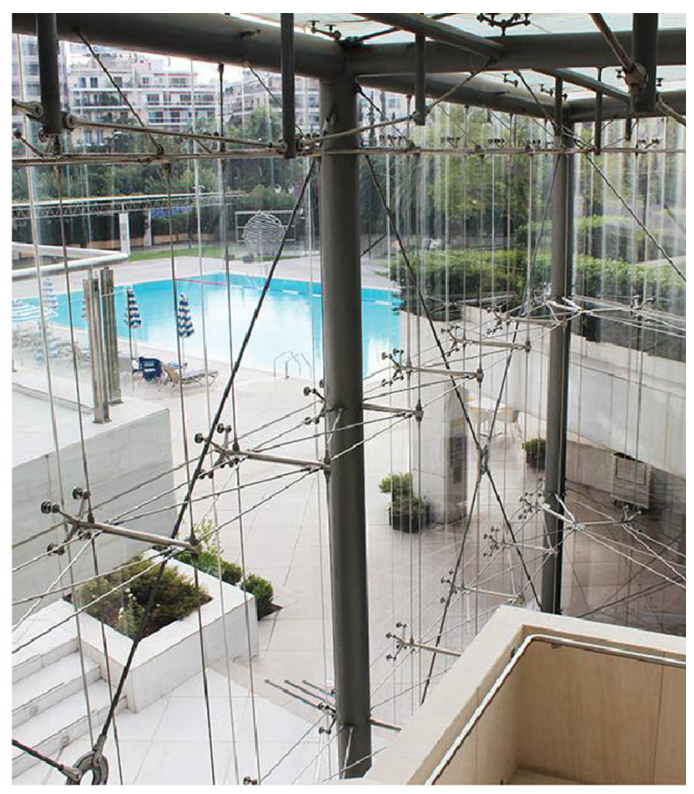

(c)

Fig. 1. Examples of glass facades. 
facades, with careful consideration for extreme loading configurations, including seismic events, blast loads, fire accidents, as well as extreme climatic loads, giving evidence of design rules, available experimental outcomes, current issues and trends, open challenges. Section 2 first summarizes some fundamental aspects related to glass mechanical features, as a material for constructions, including basic concepts for structural design. Section 3 presents then major features of design standards and requirements for extreme loading conditions, giving evidence of specific rules for applications to glazed facades. Careful consideration is paid especially for European standards in use, but including comparisons with other international standards. As shown, as a general outcome of this review paper, regulations for glass envelopes are often missing, hence requiring advanced skills when extreme loading scenarios for a given building assembly must be taken into account. In Section 4, finally, existing research related to glass facades performances under the examined loading conditions is summarized and discussed.

\section{Glass in buildings}

\subsection{Fundamentals}

Glass, which is an amorphous and normally transparent solid, is increasing in popularity as a construction material for modern buildings. It is also present throughout the built environment as a non-load-bearing material. It is conventionally manufactured by heating a mixture of raw materials in a furnace, up to the transition temperature, after which liquid glass in the melting tank is floated through tins and slowly annealed to room temperature.

From a physical point of view, glass represents a complex material, whose material characteristics varies with differences in its chemical compositions. Soda lime glass - which is commonly used for window glass - has about $72 \%$ of silicone dioxide (silica). With a higher mass proportion of silicone dioxide (about $80 \%$ ), borosilicate glass exhibits better shock resistance capacity to temperature. Borosilicate glass is therefore commonly adopted for glass reagents; however, is relatively rare to find applications in building construction. Other commonly used glass types include lead oxide glass, alumina-silicate glass, fused quartz glass etc. these have unique characteristics with different chemical compositions during manufacturing.

Ordinary glass can be be categorized by its manufacturing process into one of: float annealed (AN) glass, heat-strengthened (HS) glass and fully-tempered (FT) glass. AN glass, manufactured using a float process represents the basic glass product. Considering its rel- atively simple manufacturing method, AN glass is one of the most economic glass types, which has low strength when compared with HS and FT glasses. Heating and slowly cooling AN glass introduces surface compression in glass panes and produces HS glass. Because of the residual surface compression which forms as a result of compatibility of thermal strains through the glass thickness during the heating and the cooling stages, HS is about 2 times stronger than AN glass. According to ASTM C1048 [3], for heatstrengthened glass a surface compressive stress in the order of $24 \mathrm{MPa}$ to $48 \mathrm{MPa}$ can generally be expected. Heating AN glass to above approximately $700{ }^{\circ} \mathrm{C}$, and force-cooling it, produces FT glass. Compared to HS glass, the air-quench temperature and volume creates a much higher surface compression (above $69 \mathrm{MPa}$, according to ASTM C1048), which makes the material about 4 to 5 times stronger than AN glass. Chaudhri and Liangyi [4] describe the stress distribution across FT glass as a parabola, where the surface is under compression and the core is under tension. Due to the stored elastic energy within FT panels break into a number of small and fine glass cubes, as a result of continuous cracking once a single crack in the glass panel reaches the tensile core. This key feature of FT glass differs significantly from AN and HS glass types, which both break into jagged glass shards, normally with sharp edges. Therefore, FT glass is also often referred to as 'safety glass' as it provides mitigation against glass laceration and fracture after breakage. The cracking pattern of HS and FT glass are illustrated in Fig. 2(a) and (b)) respectively. Nevertheless, it is worth pointing out that under high-strain rate dynamic loading such as blast pressures and impacts in general, some field tests available in the literature have found that monolithic FT glass panels under explosions also break into large pieces of fragments, with sharp edges, see Fig. 2(c) $[5,6]$. This effect is because the propagation of cracks in a given FT glass panel under impact could stay within the tensile glass core and may not necessarily reach the panel surface [7]. As a result, only the tensile core of the FT glass panel would break as expected, but the entire glass panel would remain intact. Therefore, proper analysis and design of glass windows and facades in general composed of FT glass layers is generally required, especially when designing these envelopes for extreme loading conditions.

\subsection{Reference mechanical properties}

Since initial stress distributions in HS and FT glass are not uniform as a result of the manufacturing processes, most research on the materials mechanical properties are conducted on AN glass specimens and assemblies. The behavior of glass in general, from

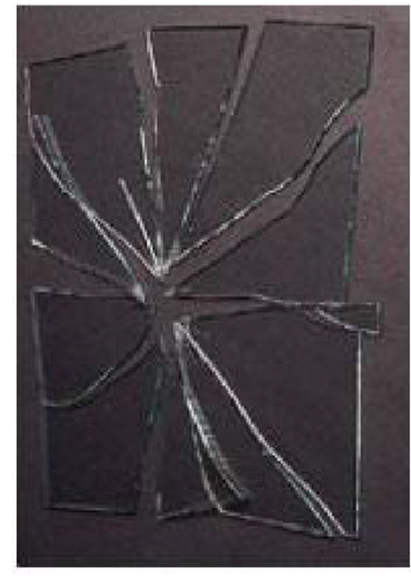

(a)

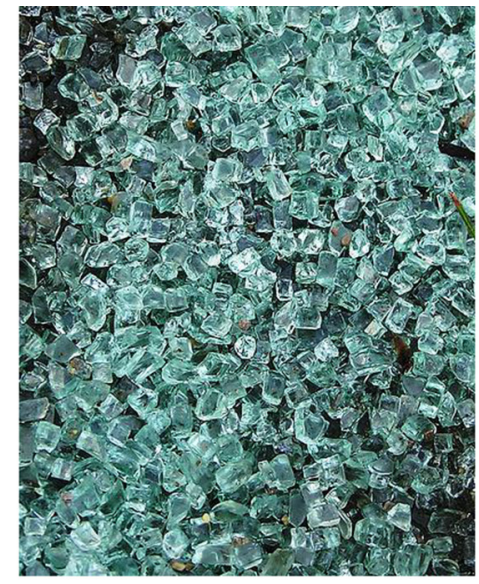

(b)

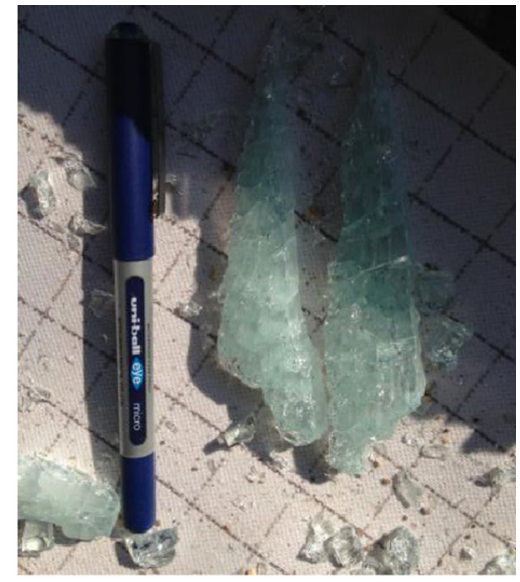

(c)

Fig. 2. Glass cracking. Examples proposed for (a) HS or (b) FT glass types, with (c) FT glass under blast [5,6]. 


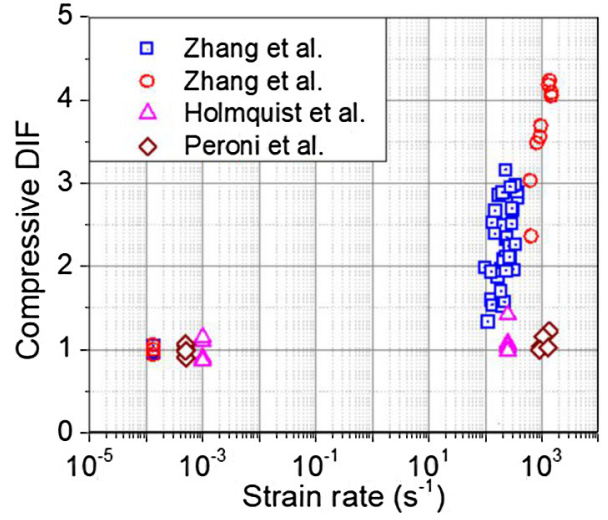

(a)

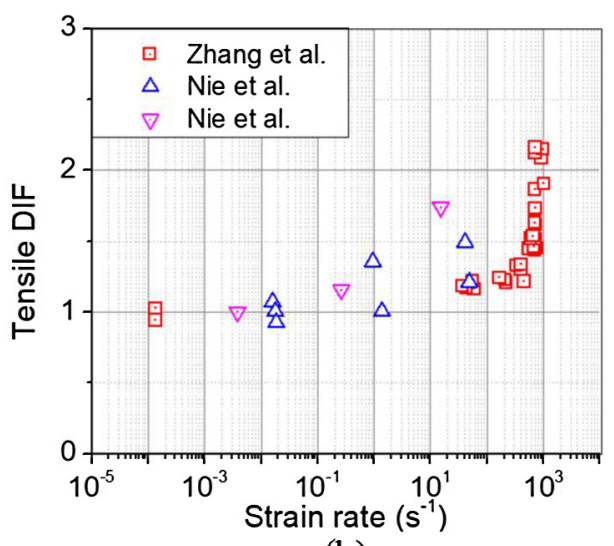

(b)

Fig. 3. Glass Dynamic Increase Factor (DIF) for (a) compressive and (b) tensile strengths, as reported in [21].

a mechanical point of view, is linear elastic and brittle in tension. Despite the fact that the theoretical strength of glass is typically in excess of 21,000 MPa [8], commercially used AN glass (i.e. for windows and facades) normally breaks below $100 \mathrm{MPa}$. This is because of the existence of micro surface flaws on glass specimens, where fractures initiate and develop [9]. The static tensile strengths of AN glass reported by different researchers and organizations - or even from the same organization - were found to vary significantly. For instance, the EU pr-EN 13474-3 [10] committee reported ring-on-ring tests on glass specimens, and there the fracture strength calculated from over 700 specimens varied from 30 $\mathrm{MPa}$ to $120 \mathrm{MPa}$. It has recently been reported that the tensile splitting strength of $15 \mathrm{~mm} \times 15 \mathrm{~mm}$ annealed glass cylinders was only around $20 \mathrm{MPa}$ [11]. The large variation in glass strength is partially because of different testing methods, i.e. bi-flexural (ring-on-ring) tests, tensile splitting tests etc. A more important factor, however, is probably the surface condition of the tested specimens as the position and direction of surface flaws on glass could greatly influence glass strength [12]. To predict glass strength, statistical methods employing either a normal or a Weibull distribution have been used to account for the uncertainties in glass material strength $[13,14]$. Some computer algorithms have also been developed to assist in determining the tensile strength of glass panels [15]. Based on the assumption of flaw size and direction on glass panel surface, a glass failure prediction model [16] was introduced to determine glass cracking strength. Many design standards such as ASTM E1300 [17] employ this model. Nevertheless, the parameters which were derived from best fitting testing data on glass panels for the glass failure prediction model have often been questioned with modification and improvement proposed $[18,19]$. In the meanwhile, many design codes such as pr-EN 13474-1 [20] employ a deterministic model where the failure of glass is based on glass allowable tensile strength.

The behavior of glass under dynamic loading varies from that under static loading. Similar to many other construction materials such as concrete and steel, a dynamic increase effect to glass material strength has been reported by some researchers [12,21-23]. Both dynamic compressive strength and tensile strength have been concluded with respect to strain rate (as shown in Fig. 3). The increase in glass strength under dynamic loading is because the roots of existing surface flaws on glass panels are subjected to stress corrosion which takes time to develop. Under dynamic loading, there is not sufficient time for glass to crack from the existing flaws. Bulk failure would result under the stress wave instead. Analytical solutions have also proven that under dynamic loading glass strength could increase as much as three times [24]. With the available testing data and existing understandings, design codes such as EN 572-1 [25] have suggested a characteristic strength of $80 \mathrm{MPa}$ for glass when designing glass windows against blast loading. This recommended glass strength indicates a dynamic increase factor of 1.78 as glass failure strength under quasi-static loading is $45 \mathrm{MPa}$ in this code.

Special care should be generally taken for glass material properties under extreme loads, involving high strain rates or fire loading, for example, as also partly emphasized in the following sections. In addition, most of the applications of glass in windows and facades typically involves not only monolithic glass panes, but laminated glass sections as well as combined insulated glass units, hence

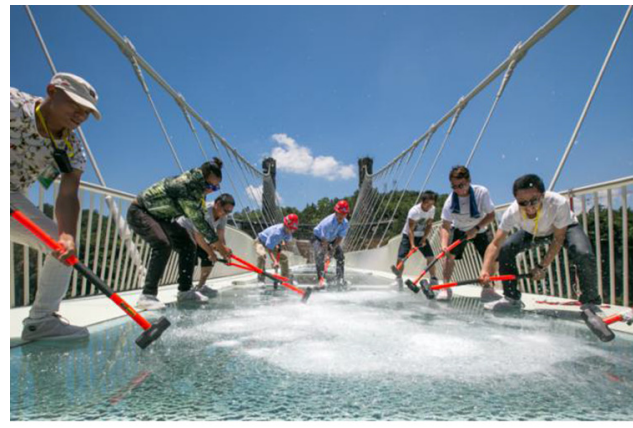

(a)

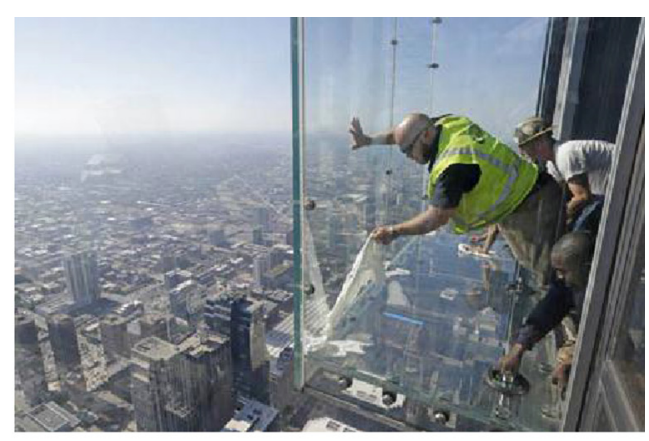

(b)

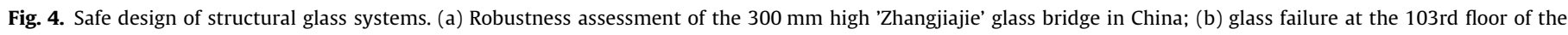
Willis Tower in Chicago (photo: AP). 
requiring further design specifications due to interaction of simple glass layers with other structural and/or non-structural materials of use in buildings.

\subsection{General design concepts for glass in buildings - Safety, robustness, resiliency}

The most fundamental aspect of designing structural glass systems in general - including facades - is to ensure appropriate structural safety (see Fig. 4). In the past decades there has been a great deal of research focusing on the safety of structural glass assemblies leading to standardization activities in order to develop comprehensive design codes for real-life applications of structural glazing. These activities - which are taking place in Europe, North America and internationally - aim to provide a common basis for structural glass design and to achieve a harmonised and consistent level of safety for various design situations and applications.

The design of structural glass facades is an continuous process from the design concept to the detailed design and verification prior to construction, which combines several methods e.g. simplified approximate calculations, accurate analytical methods, advanced numerical analysis and often prototype testing [1]. Structural design codes typically focus on the verification of individual elements comparing their response to various load effects with certain performance criteria for the given element and loading situation. This could be done in several ways following a deterministic (e.g. allowable stress based methods), semi-probabilistic (e.g. partial safety factors), full probabilistic format (Glass Failure Prediction Model [1], Crack Growth Model of Glass Strength [14]) or risk assessment [26,27]).

The two main requirements associated to structural safety of individual elements include the ultimate limit state (ULS) and serviceability limit state (SLS). ULS ensures that structural elements have adequate strength to withstand the anticipated actions without fracture or losing stability, whereas SLS requirements usually focus on deflections and vibrations, which might affect aesthetics, comfort of users or cause damage to other structural elements. Further considerations should be taken regarding durability, i.e. the long-term performance of the structural members.

Beside the verification of performance of individual elements, additional performance requirements particularly relevant to glass facades are associated with structural robustness [28]. This means that failure disproportionate to any initial damage should be avoided and includes the consideration of fail-safe design concepts typically dealing with the post-breakage behavior of individual glass elements. Robustness is fundamental when designing glass facades for extreme loading, since glass is a brittle material and the probability of its breakage cannot be fully eliminated. Therefore considerable emphasis should be put on what happens when glass breaks and to achieve safe failure, i.e. prevent injuries and collapse of the structure [29]. According to Bos [30], robustness in glass structures can be introduced at 3 different levels: the material level, the component level and the structural level. At

Table 1

Classification of action, in accordance with [31].

\begin{tabular}{lll}
\hline Permanent action & Variable action & $\begin{array}{l}\text { Accidental } \\
\text { action }\end{array}$ \\
\hline $\begin{array}{l}\text { Self-weight of structures, fittings } \\
\text { and fixed equipment } \\
\begin{array}{l}\text { Prestressing forces } \\
\text { Water and soil pressures }\end{array}\end{array}$ & $\begin{array}{l}\text { Imposed floor loads } \\
\text { Wind loads }\end{array}$ & $\begin{array}{l}\text { Fire } \\
\text { Impact from } \\
\text { vehicles }\end{array}$ \\
$\begin{array}{l}\text { Indirect actions, e.g. settlement of } \\
\text { supports }\end{array}$ & $\begin{array}{l}\text { Indirect actions, e.g. } \\
\text { temperature effects }\end{array}$ & \\
\hline
\end{tabular}

the material level, the robustness can be enhanced through increasing the strength by changing the type of glass. At the component level, the load bearing capacity can be improved by e.g. adding sacrificial glass panes and not fully considering them in the design calculations. Finally, at a structural level the system can be designed in such a way that should one (or several) individual elements fail, the entire façade system should survive and maintain integrity.

\section{Available design standards for glass system under extreme loads}

\subsection{General}

Design of structural glass facades and curtain systems, in general, follows recommendations, approaches and conventions traditionally in use for buildings and other construction components. According to Eurocode 1 (Actions on structures - Part 1-7: General actions - Accidental actions), as known, design actions and loads of interest for buildings and infrastructures are divided into different classes, depending on their relevance, see Table 1 and [31].

There, extreme loading configurations, including natural, accidental or human-induced events, are only marginally considered. In addition, no specific regulations are provided for structural systems generally composed of glass, as also highlighted in the following sections.

In this context, the current review paper aims to explore existing design regulations and research studies that are mainly related to exceptional loadings in facades. Careful consideration is spent for:

\section{- Earthquakes}

- Explosions (external to the building), even accidental or humaninduced

- Fire accidents

- Extreme climate conditions

For sake of clarity, further extreme design actions with crucial effects on load-bearing glazing systems and facades, but with mostly local application and minor influence on the full building response, like for example impacts (i.e. bird strikes or human bodies $[32,33]$, ballistic impacts [34-36], etc.) are not explicitly discussed in this review paper.

In general terms, in accordance with available design standards and regulations for buildings under exceptional loads, a key role in design assumptions and performance limitations is given by the role assigned to glass systems and assemblies acting as a part of a whole building. For a secondary component made of glass, compared to the primary building structure, partial damage is in fact generally accepted by current design standards (see for example Section 3.2). This is not the case of structural assemblies of primary importance within a given building system. There, supposing to design glazing envelopes, all the glass elements or facade components should in fact able to properly resist to the anticipated design loads, as well as to accommodate the overall deformations of the building frame imposes to them, as a full three-dimensional assembly, including both out-of-plane and in-plane displacements. In the latter case, it is expected that special joints, mechanical connectors and fasteners would be required, together with careful consideration for connections detailing, in order to satisfy design standard limitations and avoid severe damage. Also in the latter case, however, no specific rules are available for glass curtain walls designers.

The major issue in current design practice arises then from conventional assumptions in use, since contemporary building envel- 


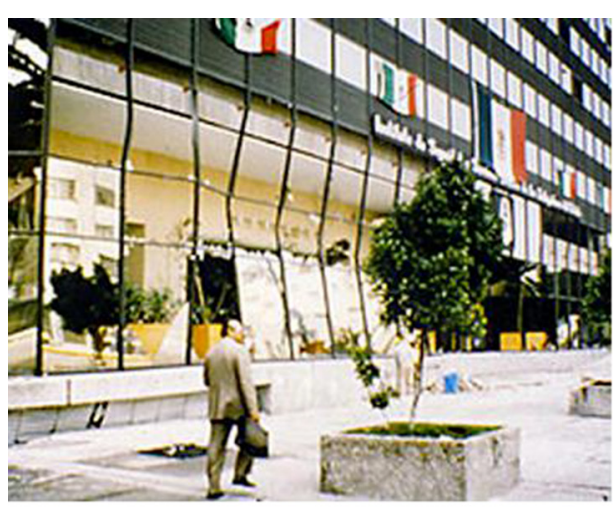

(a)

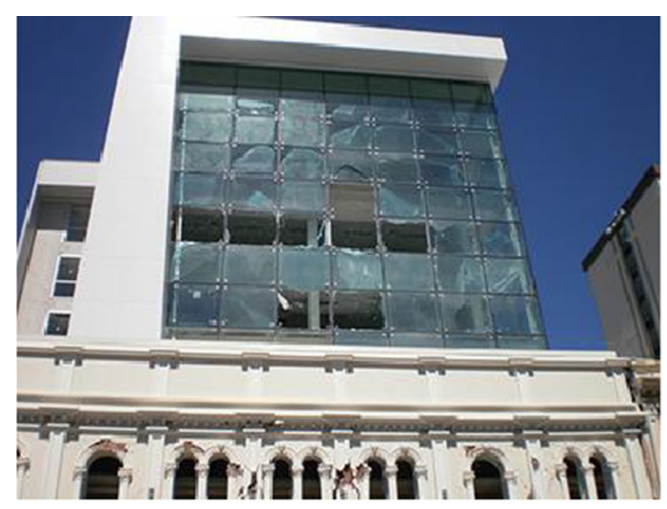

(b)

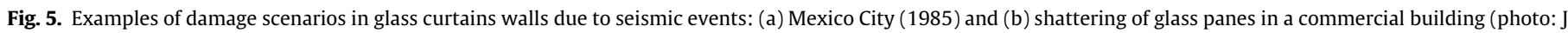
Bothara).

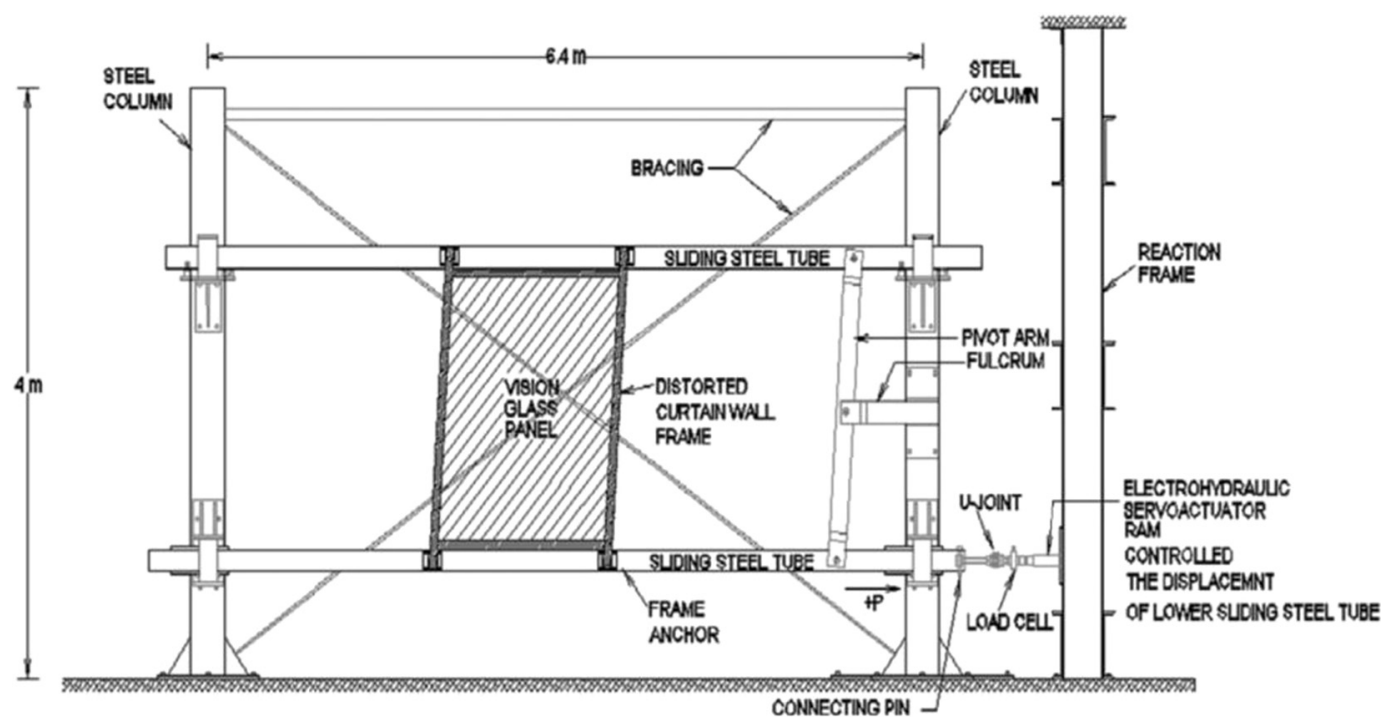

Fig. 6. Dynamic racking test facility for curtain walls $[41,42]$

opes are in most of the cases regarded as nonstructural components, hence intended as building elements which are not designed to contribute to the structural capacity of the load-bearing frame, although they may significantly affect their dynamic properties. Unfortunately, this definition is somewhat misleading, since it implies that nonstructural elements have 'no structural role' [37].

\subsection{Seismic events}

Generally, given a traditionally framed glass unit, no consideration is given by standards to properly assess and optimize its real performance under seismic loads. As a general rule, most of the seismic requirements for nonstructural components focus on providing adequate clearance gaps, to accommodate the relative horizontal displacements of primary buildings during design earthquake events. In this sense, damage due to earthquakes is expected and accepted, see Fig. 5.

Regarding the seismic verification of glazing envelopes in Europe, for example, common standards in use for seismic resistant buildings can be applied also to curtain walls, but without any additional specification (see for example [38]). In that document, in fact, secondary components are only accounted, and no specific regulations are available to consider the importance or typology the curtain wall belongs, as well as for detailing, anchoring systems, materials, etc. As a general rule, the building to verify - as a whole structural assembly - is in fact required to do not exceed specific inter-story drift values. The mentioned EU regulations are in line with other standards for seismic design of buildings, see for example the New Zealand NZS 1170.5 document [39].

More detailed provisions are indeed included in US FEMA 450 [40], even for the so called "secondary non-structural cladding systems" only. There, compared to the EU or NZS scenarios, specific drift limit values are given for 'glazed curtain walls', 'storefronts' and 'partitions', and hence should be satisfied to avoid glass fallout during a seismic event.

Currently, the only practical approach to demonstrate acceptable seismic performance is based on costly, full-size testing (Fig. 6). The American Architectural Manufacturers Association (AAMA) recommended the use of a static full-size test approach as a standard testing procedure for the seismic performance of curtain walls and storefront walls [41,42]. Performance of the wall system mock-up is then evaluated by the design professional based on its observed response and comparisons with pre-established seismic performance criteria. Of course, this approach is highly 


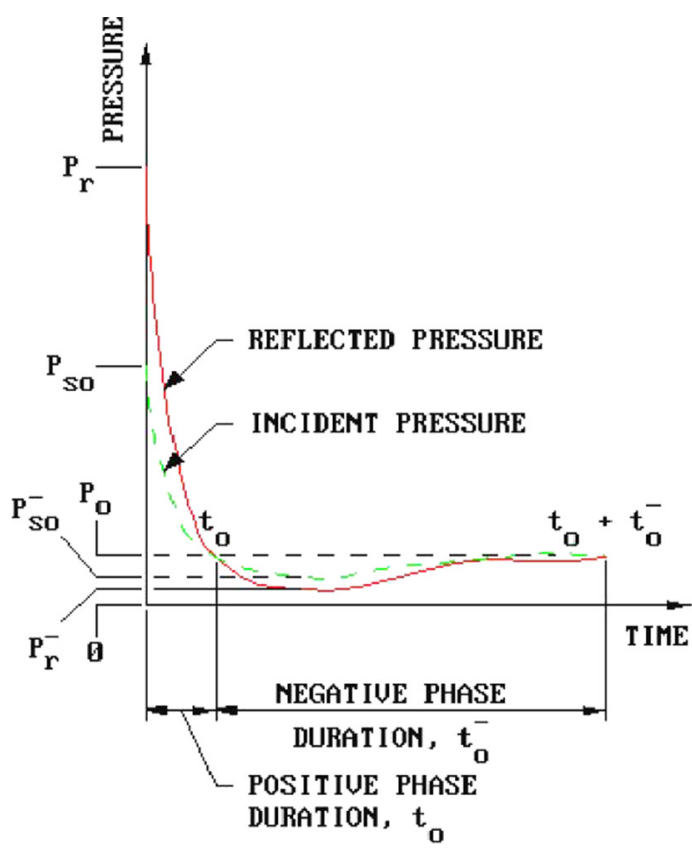

(a)

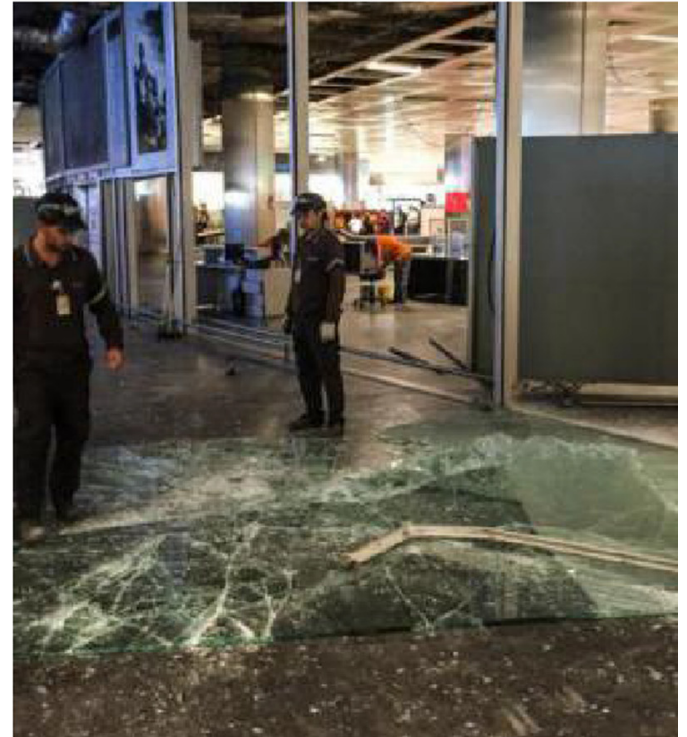

(b)

Fig. 7. Blast-loaded glazing facades. (a) Pressure time history, with evidence of incident and reflected pressure [43]; (b) typical scenario after bombing.

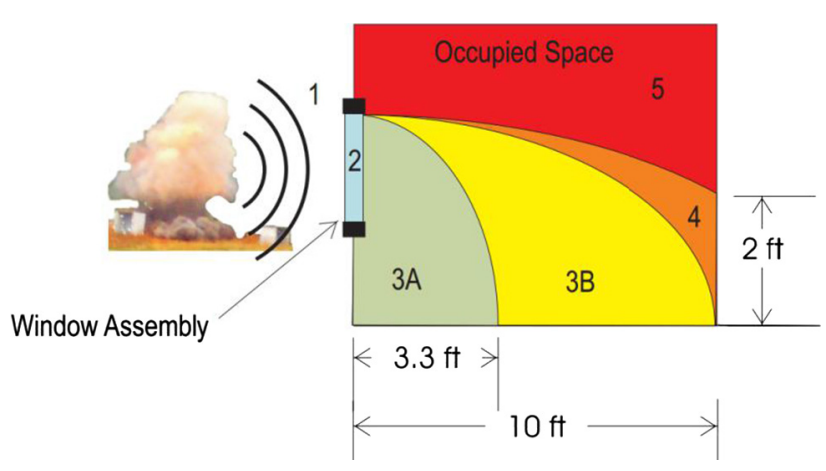

Fig. 8. Criteria of fragments threat, in accordance with GSA TS-01 [45].

expensive, especially for small building projects. Thus, alternative procedures for the seismic design of architectural glass cladding are urgently needed.

\subsection{Blast loads}

Accidental or man-made explosions are typically characterised by a rapid and sudden release of energy in the form of shock wave, light, heat and sound. These shock waves consist of highly compressed air traveling at supersonic velocity. When shock waves hit the front surface of a structure or building, they are then reflected and amplified. Given an explosive event, the magnitude of the overall incident blast pressure is usually defined as a function of the equivalent charge weight of TNT, the geometry and stand-off distance from the centre of the charge to the wave front. The peak pressure of the compressed wave decays very rapidly, typically in times of the order of milliseconds. The initial compressive shock wave is followed by a vacuum as a result of gas and material being expelled rapidly from the point of detonation. This results in the application of a negative pressure (or suction) on the surface of the exposed structure after the initial decay of the com- pressive wave front and before the pressure returns to ambient (see Fig. 7(a)).

For buildings and structural systems which are not designed with blast loads specifically in mind, air-blast waves generally impinge on the external envelope, leading to the failure of glass windows and facades (i.e. Fig. 7(b)), entering the buildings and resulting in possible damage or even collapse of columns, beams, and slabs. In some conditions, progressive collapse could also be triggered. Special care should be taken for glass facades under blast, since the majority of casualties in a blast incident are associated with glass fragment injuries.

In terms of structural design and analysis of blast targeted systems, empirical methods are conventionally used (see for example [44] for comparative case studies).

Note that the Eurocode 1 [31] mentions only internal 'explosions' as possible accidental loads to take into account. The effects due to the antagonistic explosions are outside the scope of the standard, hence other more specific guidelines should be taken into account for this threats concerning glass facades and structural systems in general.

Design codes for blast-loaded structures such as GSA TS-01 [45], in this regard, classify the threat from glass fragments based on their splash distances into a given occupied area (Fig. 8). According to the GSA code, glass windows that do not break or break but managed to retain fragments within frame members are rated as 'no threat'. If glass fragments are supposed to fail within $1 \mathrm{~m}$ distance from the opening, the threat is rated as 'very low'; when the fragments fly higher than $0.6 \mathrm{~m}$ at $3 \mathrm{~m}$ distance, the hazard level is rated as 'high'. Mostly similar glass fragment assessment criteria are also available in other design documents, like for example [46-49]. Nevertheless, it should be first noted that evaluations rules collected in these technical documents can only be applied to glass windows with specific features and dimensions. In addition, velocity, size, shape etc of the. fragments are not considered in defining the threat level in all the mentioned standards.

A review on design strategies limiting the effect of blast loading and explosions in the context of multi-functional buildings is given by Lange in [50]. Several points of the discussion there are valid for 
the design of glass facades as well. In general, preventing damage to a glass façade may rely on much of the structural engineering guidance intended to prevent disproportionate collapse and provide adequate robustness.

As a starting point for glass facades the Unified Facilities Criteria which has been published by the US Department of Defence for the design of structures for accidental loading which gives detailed information about the design of concrete and steel structures for blast loading [51]. According to this document, design strategies for designing structures to resist the impact of terrorist actions include the following:

- Maximising standoff distances

- Preventing building collapse

- Minimising hazardous flying debris

- Providing an effective building layout

- Limiting airborne contamination

- Providing mass notification

Maximising stand-off distance clearly addresses the magnitude of the side-on overpressure through the relationship described in Fig. 8. Similarly, providing an effective building layout limits the potential damage by affecting, for example, the ability to place or deliver an explosive device or even potentially by reducing the reflection factors thereby reducing the magnitude of any impulse from the incident pressure.

\subsection{Fire}

Facades are an important consideration of the fire safety strategy of a building. They may be a source of flame spread vertically and horizontally along the external surface of the building, and if not correctly detailed they may also provide a means for fire to spread vertically between the floors of a building. Colwel and Baker [52] provide a summary of the two risk scenarios (external and internal fire incident, where the internal fire has been allowed to develop and flashover) as well as the mechanisms by which fire can spread within a building via the external envelope. These mechanisms may be summarized as follows:

- An external fire, or external flaming from a post-flashover compartment fire interacting with the facade material and leading to flame spread along the surface of a facade

- Flames entering any cavity in a facade may result in rapid fire spread vertically within the cavity as a result of a chimney effect, whereby hot gases rising draw additional air into the facade, leading to longer flames and more rapid flame spread

- Fires may re-enter the building either as a result of weaknesses in the window detailing or as a result of broken glazing above the original fire source. These flames could be the result of either flame spread on or within the facade or external flaming from the original fire.

Currently, the European Union lacks a harmonised large-scale reference test and classification system for façades which reflects the behavior of these construction products in real-life fire scenarios. The Construction Products Regulation (CPR) provides a general regulatory framework for the performance of construction products in Europe [53]. The document provides five basic requirements for construction works and building products regarding safety in case of fire:

- the load-bearing capacity of the construction can be maintained for a specific period of time;

- the generation and spread of fire and smoke within the construction works are limited;
- the spread of fire to neighboring construction works is limited;

- occupants can leave the construction works or be rescued by other means;

- the safety of rescue teams is taken into consideration.

As a result of this a complete evaluation of a glass façade should take into account the following issues: the fire resistance, fire spread on and within the façade, heat release rate, falling parts and burning droplets. Close attention should also be paid to detailing, such as cavity barriers, penetrations, ventilation cavities, window openings. Regarding the safety of occupants and rescue teams the evaluation should also include assessment of potential toxic fumes generated during fire.

Despite this, the majority of Member States of the European Union only refer to the EN 13501-1 reaction to fire and/or EN 13501-2 fire resistance classification system for the required performance of facades. This does not account for the fact that façades are a system and it is the system performance which governs much of the above.

The standard EN 13501 consists of six parts and is related to the classification of construction products and building elements for fire. The first part of EN 13501 [54], relates to the classification of construction products based on the results of reaction to fire tests. The standard classifies materials and components according to seven Euro-classes based on the reaction of the material (or component) to a heat source in a Single Burning Item (SBI) test performed according to EN 13823 [55]. Classification is done based on flame spread to obtain an A1, A2, B, C, D, E, or F classification; while various sub classes reflect other performance criteria such as, heat release rate, smoke production.

Some information about combustibility of glass can be found in CWCT Technical Note 98 [56] and Commission Decision 96/603/EC [57]. Glass not containing organic materials, such as basic glass, coated glass, toughened glass, heat strengthened glass, chemically strengthened glass is classified as class A1 (non-combustible), whereas laminated glass, due to the presence of certain amount of organic material (interlayer), is classified as B, C or D (depending on the relation of volume of glass and interlayer material). However, the SBI test is a medium scale test method which is meant to provide similar results to a so-called room corner test; a scenario which is based on an item burning inside of a compartment in a building. The SBI and the Euro-class system are therefore arguably not applicable as a test or classification method for façade construction. Finally, CDCT Technical note 98 states, that 'laminated glass is generally not considered to increase the risk of fire spread and its use is considered acceptable above $18 \mathrm{~m}$ ' [56]. The second part of EN 13501 [54], focuses on the classification of construction elements based on fire resistance testing. This results in a classification of various criteria, the most common being $R, E$ and $\mathrm{I}$; $\mathrm{R}$ being a classification of the load bearing capacity in fire; $\mathrm{E}$ being a classification of the integrity and I being a classification of the insulating properties of the product. The REI classification is usually followed by a period of $30,45,60,90$ or 120 min during which time the product has not failed any of the limiting criteria for these classifications.

In response to the lack of a harmonised testing standard or classification system, several EU countries have introduced their own tests in national fire safety regulations. Of a recent survey of the Member States, 14 of them responded that they refer to one of 11 different test standards [58], examples are shown in Fig. 9. This leads to the need for facade system manufacturers to carry out several fire tests in order to be able to sell their products in more than one country.

The majority of facade testing methods are based on a very similar concept, and all of them account for the required testing of a facade as a complete system in case of fire: a vertical wall of ca. 


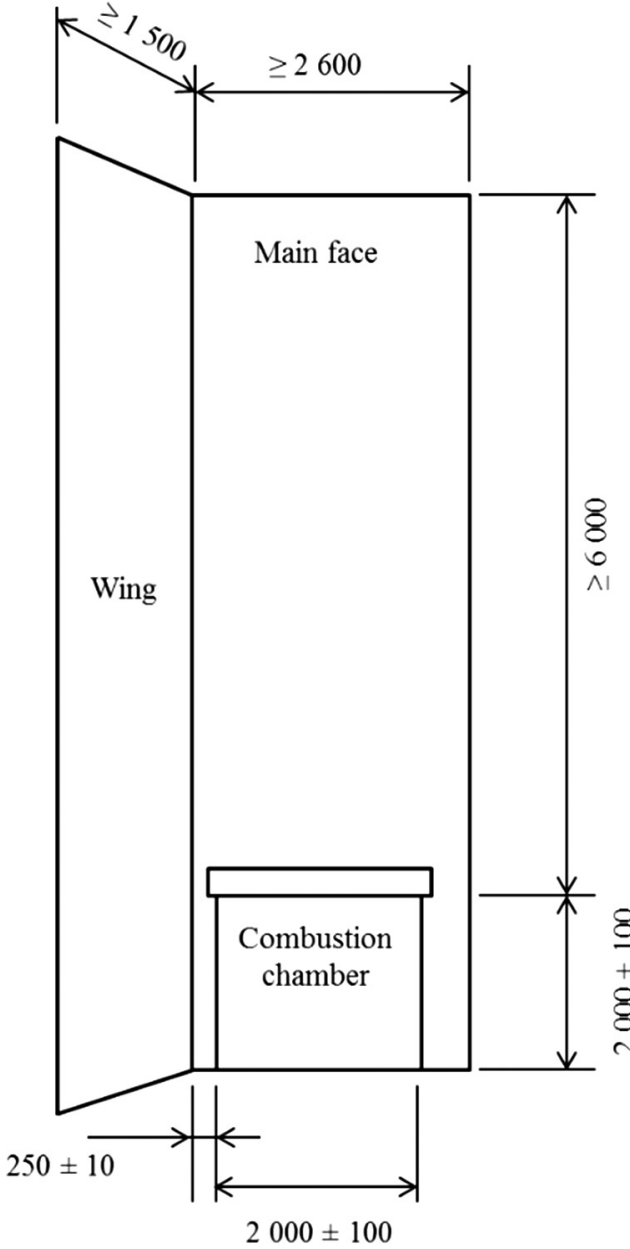

(a)

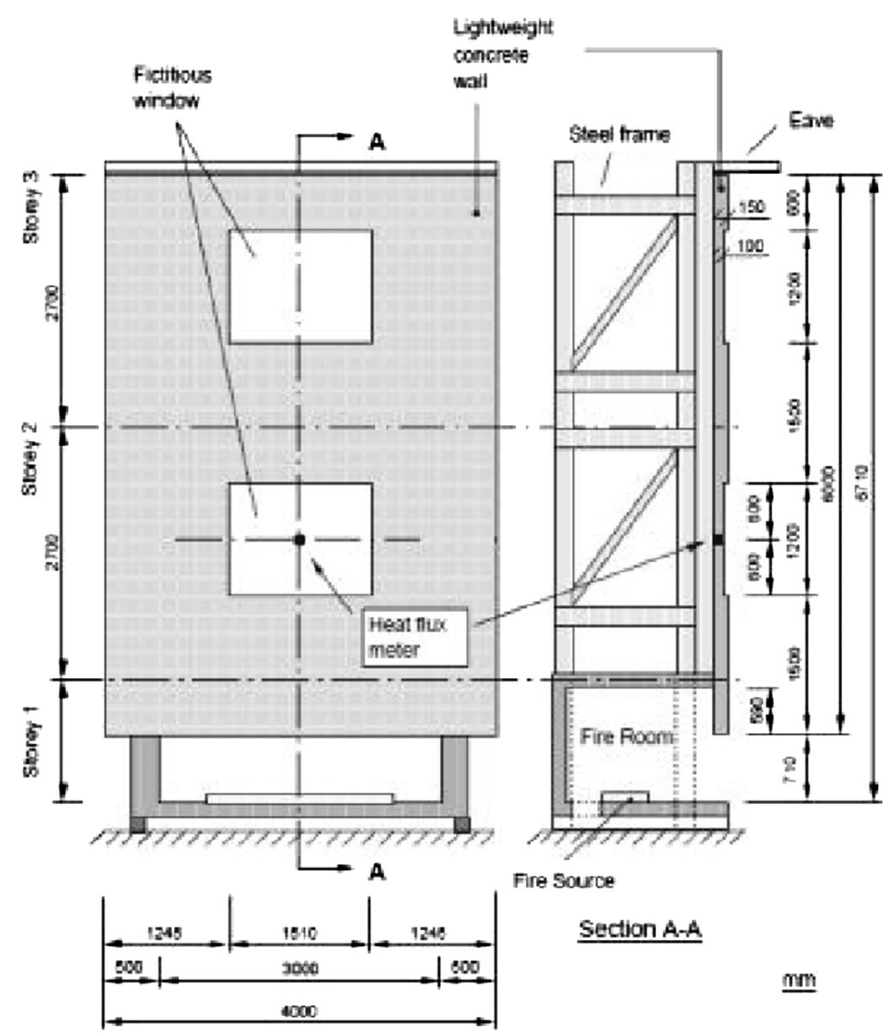

(b)

Fig. 9. Examples of facade fire test rigs with and without return wings (dimensions given in mm): (a) BS 8414 [59,60], and (b) SP Fire 105 [61]

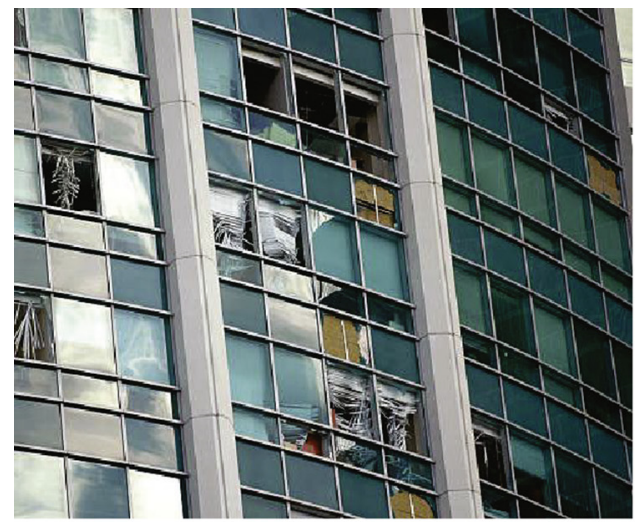

(a)

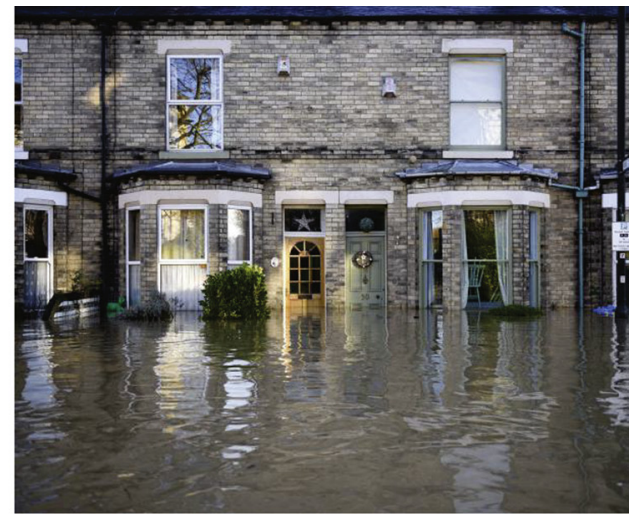

(b)

Fig. 10. Damaged glass facades due to extreme weather conditions after (a) hurricanes and (b) floods.

8 to $10 \mathrm{~m}$ height, with a compartment at the base intended to represent a fire which could go to flashover, leading to external flames impinging on the facade surface. The main differences between the test methods can be identified in the following parameters: the fuel load in the combustion chamber; the height of the wall; the presence or lack of a return angle on the wall; the presence or lack of window detailing. Differences in the resulting classifications are based on, for example: observation or not of falling parts and falling droplets; and height which flame spread should not exceed; observation of horizontal and vertical flame spread; presence or 
absence of window detailing or a starter track at the base of the facade; or measurement of heat fluxes at representative window openings.

At the time of writing, there is an ongoing project within Europe, funded by DG GROW, to develop a harmonised test and classification method for Europe. This should be based on the existing British Standard BS8414-1 and part $2[59,60]$ as a full scale test method, and the German DIN 4102-20 [62] as a medium scale test method. The obvious end result of such an initiative should be a harmonised methodology and classification system for the fire performance of facades based on a test that reflects real safety risks and which could be incorporated in the regulations of all of the Member States.

\subsection{Climatic loads}

Due to the significant climate change and increasingly unpredictable weather patterns, extreme loads such as freezing precipitations, snowfalls and snow storms, windstorms, heavy precipitations or floods and hurricanes represent additional extreme scenarios for structures, requiring specific design considerations. This is true especially for glazing curtains (see Fig. 10), due to their intrinsic vulnerability to dynamic loads, high strains and shocks in general, hence careful consideration should be spent in design as well as in retrofitting.

In this review paper, focusing on glass vertical partitions such as windows and facades, careful consideration is paid to extreme wind loads and floods only. Worth noting - in accordance with recent events - is also the possibility of extreme snow design loads, which could represent a major issue and challenge in the design of glazing roofs and indirectly affect the structural performance of the attached facades. Another design action with crucial effect on the overall performance of load-bearing facades is represented by extreme temperature exposures, here not discussed.

\subsubsection{Wind}

In terms of climate loads, Eurocode 1 [31] describes the procedures to calculate wind loads on facades in part 1-4, enabling the assessment of wind actions for the structural design of buildings and civil engineering structures up to a height of $200 \mathrm{~m}$. The wind actions are given for the whole or parts of the structure, e.g. components, cladding units and their fixings.

As a convention, the characteristic 10 min mean wind velocity at $10 \mathrm{~m}$ above ground of a terrain with low vegetation is considered.

However, the Eurocode 1 does not give guidance for wind design calculations on special structural systems, where local thermal effects, torsional vibrations and higher vibration modes or aeroelastic phenomena should be properly taken into account. In the case of traditional buildings, in addition, several past events of extreme weather conditions pointed out in fact the deficiency of such guidance, since the maximal design value for wind is usually significantly lower than real values measured over the past decades.

Data reported in the literature (i.e. $[63,64]$ ) show in fact that in many regions of Europe, the 5-year and the 50-year return levels were exceeded by the $10 \mathrm{~m}$ wind speeds. Extreme events are frequently recorded in the Asia-Pacific region as well as in US [6568]. In December 1998, Croatian instruments measured maximum wind speeds up to $248 \mathrm{~km} / \mathrm{h}$ (Maslenica bridge, southern Croatia region). Within further past notable events in Europe, windstorms like Lothar and Martin (December 1999) have to be mentioned, since extreme $10 \mathrm{~m}$ wind speeds were measured. Just $300 \mathrm{~km}$ in diameter, Lothar's compact internal pressure gradients were found to be comparable to those of a 'category 2' hurricane, with wind gusts up to $210 \mathrm{~km} / \mathrm{h}$ in several regions of Europe. In the same per- iod, the winter storm Martin brought gust wind speeds of $190 \mathrm{~km} /$ $\mathrm{h}$ to the French coast. Windstorm Kyrill in West, Central and East Europe (January 2007) caused wind gusts up to $120 \mathrm{~km} / \mathrm{h}$.

\subsubsection{Floods}

Another extreme load deriving from climate changes, which is often neglected in design analysis of building structures, is represented by flash and river floods (i.e. Fig. 8(b)). Even more frequent in the Asian and Pacific regions or US [69-73], such hydrometeorological event can be observed several times each year also in Europe, that is quasi-stationary or so called back-building storms punching heavy rain for several hours over the same area, resulting in flash floods that destroy local streets and bridges, hence requiring careful consideration and appropriate strategies [74-76]. The maximum accumulated rain is rarely measured in such events, but seems often to be well above $100 \mathrm{~mm}$ within one or two hours.

\section{Glass facades under extreme loads - Existing research}

\subsection{Seismic events}

Although the main building frame has been a prime research topic in structural engineering, the building envelope has received much less interest from designers and researchers. The implications of this inequity are gaining growing attention since extensive failures of these structural elements and their connections are starting to represent the main seismic consequences in terms of casualties and economic losses (see also Fig. 5).

In fact, research into the seismic performance of structural frames has yielded impressive results, making it unlikely that well design building frames will collapse under massive earthquakes. However, post-earthquake surveys and laboratory tests on glazing assemblies have shown that these systems are susceptible to extensive damage as a result of earthquake-induced inter-story drifts in the building frame, which usually have to be absorbed by the clearance between the glass panes and the framing members. This damage includes serviceability failures, such as glazing gasket dislodging, sealant damage, glass edge damage, and glass cracking, which often require expensive, disruptive, building envelope repairs, but can also lead to more serious failures such as falling glass and falling wall system components, which present a potentially serious life safety hazard. Such failures can impose large liabilities to building designers, building contractors, building owners, and insurers.

Glazing systems can be designed using a variety of glass types, configurations for glazing frame construction type, and method of glass-to-frame attachment. Under earthquake-induced building inter-story drifts the response of different designs is generally different. With widespread use of various types of glazing systems, a growing need exists for better understanding of the behavior of such systems under earthquake effects and how to design them for safety and serviceability concerns [77].

Recent earthquakes have revealed the vulnerability of glazing systems to seismic damage according to reconnaissance reports [78-83]. These documents confirm that earthquake damage has occurred in glazing systems containing glass components on buildings that have experienced little or no damage to the primary structural system [84]. The damage to the glazing systems is usually the result of an incompatibility between the deformation characteristics of the structural framing and the movement capability of the cladding, e.g. insufficient perimeter joint widths and lack of slip-accommodating connections.

There are two major concerns related to the performance of glazing systems during and immediately following seismic activity. 

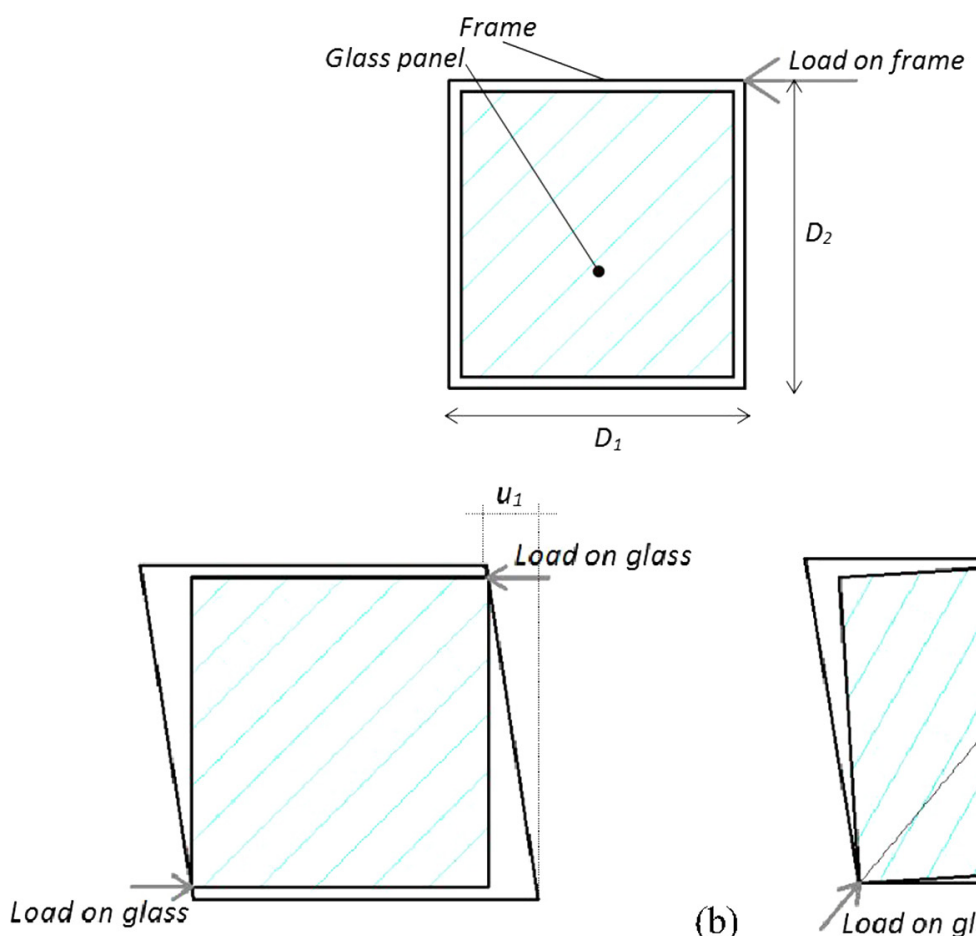

(a)

(b)

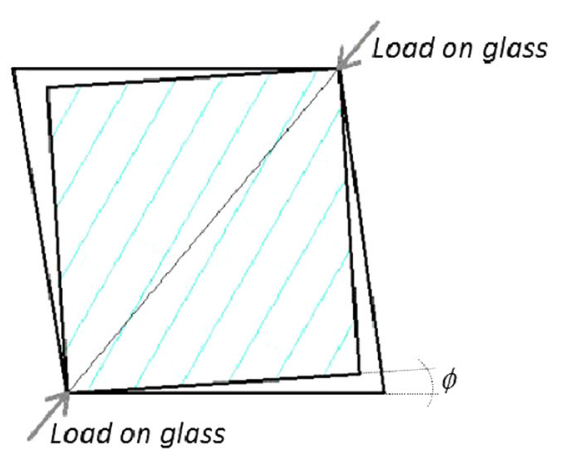

(c)

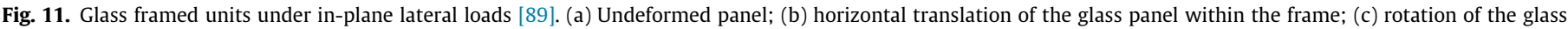
panel within the frame, with evidence of reaction forces in glass.

Hazards to people from falling glass, including injuries and fatalities at street level from shattered elevated windows, and building downtime and cost to repair. Bringing operations in a building 'back to normal' can be prevented by a breached building envelope due to glazing and glazing system damage. Of increasing concern, especially to insurance interests, are the costs of repair to glazing systems in light to moderate earthquakes. Often a glazing system shows no external signs of damage, yet may eventually need to be replaced as a direct result of the seismic activity. Glazing can shift, roll off its setting blocks and/or sustain edge damage that is not always visible by external inspection. Other areas of concern are loss of building security, damage to building interiors during post-earthquake and disruptions to building operations. These disruptions are typically caused when building envelopes are breached as a result of seismic activity or other natural and manmade conditions.

Published studies related to the use of finite element analysis to predict the performance of glazing systems under seismic loads are scarce [85]. One reason for the slow development in this area is precisely the fact that curtain walls are considered as 'nonstructural elements', which implies a lack of justification for the efforts required for advanced structural analysis.

Adequate research is not currently available concerning the seismic performance of contemporary glass curtain walls. Current building codes do not contain explicit provisions for the seismic design of glass components. Also standard test methods for evaluating the seismic performance of glazing systems are mostly developed by a consensus process.

Only a few researchers have conducted experimental research on the seismic performance of currently used glazing systems. Bouwkamp and Meehan [86] investigated the performance of window panels subjected to racking loads. Cupples [87] performed racking tests on a Robertson-Cupples curtain wall system to evaluate the overall performance of the wall system and evaluate the glass-to-frame connection details. Lim and King [88] investigated the seismic performance of curtain wall systems at the Building Research Association of New Zealand, including in-plane dynamic racking tests on full-scale glass and aluminum curtain wall assemblies. In [89], research studies gave evidence of local effects in frame supported glass curtain walls under in-plane loads, see Fig. 11.

In the early 1990s Richard Behr and a team at the University of Missouri, Rolla and later at Pennsylvania State University, University Park, began a long-term program of experimental testing of the seismic behavior of a number of glazing systems. These included store-front glazing, curtain walls with a variety of glass types and glazing techniques, and glazing with applied films, see [9093]. This work led to a number of recommended revisions to the NEHRP Recommended Provisions for the Seismic Regulations for New Buildings and Other Structures FEMA 450 which were published in the 2000 NEHRP Provisions FEMA 451 [94]. Members of the team participated in developing a recommended Dynamic Test Method for Determining the Seismic Drift Causing Glass Fallout from a Wall System, published as AAMA 505.6-01 [41] and referenced as 'Recommended Static Test Method for Evaluating Curtain Wall and Storefront Systems Subjected to Seismic and Wind Induced Inter-story Drifts' in the 2000 NEHRP Provisions [42]. The new NEHRP seismic design provisions for glass and the new AAMA seismic test method for glass have been adopted in American Society of Civil Engineers, see [95], which is referenced in the International Building Code [96] and NFPA 5000: 'Building Construction and Safety Code'.

Past research studies included the use of rounded corners for glass panels, to reduce damage. Experimental testing generally manifested significant gains for drift accommodation. Further investigations on the topic resulted in the development of an 'Earthquake-Isolated Curtain Wall System (EICWS)' that decouples each story level of the system structurally from adjacent floor levels [97]. The seismic joint is able to accommodate relative inter-story movements while still maintaining a building envelope 
weather seal. In-plane and out-of-plane movements are accompanied by horizontally continuous, flexible, elastomeric gasket loops that act as weather seals between stories. Alternative concepts to improve the seismic performance of conventional cladding systems are mostly based in 'swaying mechanisms' with slotted hole connections, and hinged "rocking mechanisms". The ability of slotted hole connections to accommodate imposed seismic motions can be hindered by improper joint assembly and by the longterm effects of corrosion. Complex rocking systems have been proven to lead to several on-site installation errors, causing early failures of the rocker connection.

\subsection{Blast loads and explosions}

Research on the performance of glass windows/facades under blast loading date to World War II when a large amount of blast tests were carried out with frangibility curves of glass windows derived with different explosive scaled distance [98,99]. Around 1980 s, extensive studies were performed by US navy and government officials. In the wake of Irish terrorist bombing attacks on British barracks, substantial studies were conducted by the UK government with empirical design approaches drafted [3]. Most of these studies were based on field blast testing results with certain window dimension. The accuracy of the above studies and approaches on glass windows other than these investigated parameters is therefore not guaranteed. More and more experimental, numerical and analytical studies have been carried out by researchers throughout of the world on the behavior of glass windows/facades under blast loading, as also summarized in this Section. As a common aspects for these studies, the attention of designers to high vulnerability of glazing facades to blast loads and the increasing number of tragic, human-induced events can be found (i.e. [100]).

Considering the relatively lower cost, monolithic glass pane has been overwhelmingly utilized for glass windows/facades. Many laboratory shock-tube tests and field blast tests have been carried out over the years. Recent studies include Zhang's [5] blast test on full-scale monolithic FT glass (see also Fig. 2(c)) and Ge et al.'s experiments on monolithic AN glass windows [101]. In [5] it has been reported that under blast loading, monolithic glass windows break with two typical failure modes: planer failure and spherical failure modes. Glass panel fails with spherical failure pattern which relates to the flexural response of glass panel - when the loading duration is relatively long. Planer failure mode, conversely, is associated to the shear response of the panel and is more likely to occur when the loading duration is relatively short.

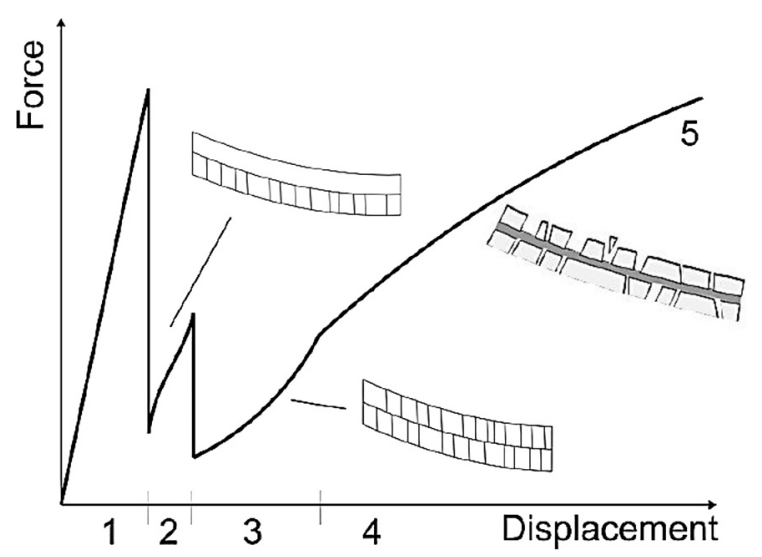

Fig. 12. Schematic deformation-to-failure process for laminated glass [105].

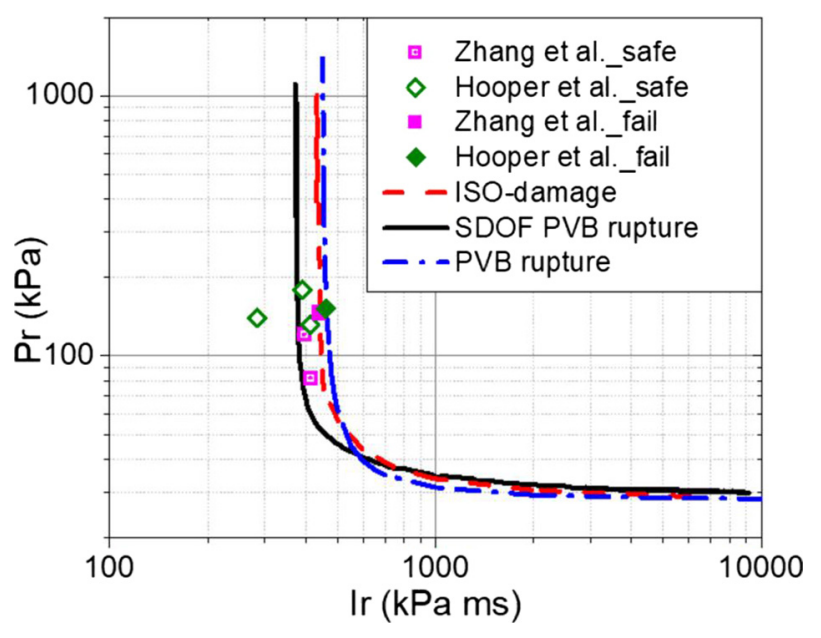

Fig. 13. Comparison of P-I diagrams for $1500 \times 1200 \mathrm{~mm}$ laminated glass windows [21].

Since ejecting glass fragments towards residences contributes to the majority of personnel injuries in blast incidents, studies on the characteristics of glass fragments from broken glass windows/facades are very important. In this regard, a relatively high number of experiments have been performed to investigate glass fragmentation. For instance, van Doormaal et al. correlated fragment velocity with reflected overpressure and impulse for annealed glass windows [102], while Fletcher [103] and Iverson [104] assessed the biological impacts of glass fragments. Available analytical solutions have key role for design purposes in blast-loaded glazing facades, but existing methods for the prediction of glass fragmentation are primarily based on semi-analytical with constants of formula from field blast test [101].

To improve the blast resistant capacity and mitigate fragment threats, laminated glass solutions comprising two or more layers of glass panels sandwiched by polymer interlayers are widely used and represent, since decades, the conventional 'safety glass' for impact and shocks. Fig. 12 describes response of laminated glass under blast loading, which can be explained by the following five stages:

(1) glass plies deform elastically,

(2) the outer glass ply breaks,

(3) the inner glass ply cracks.

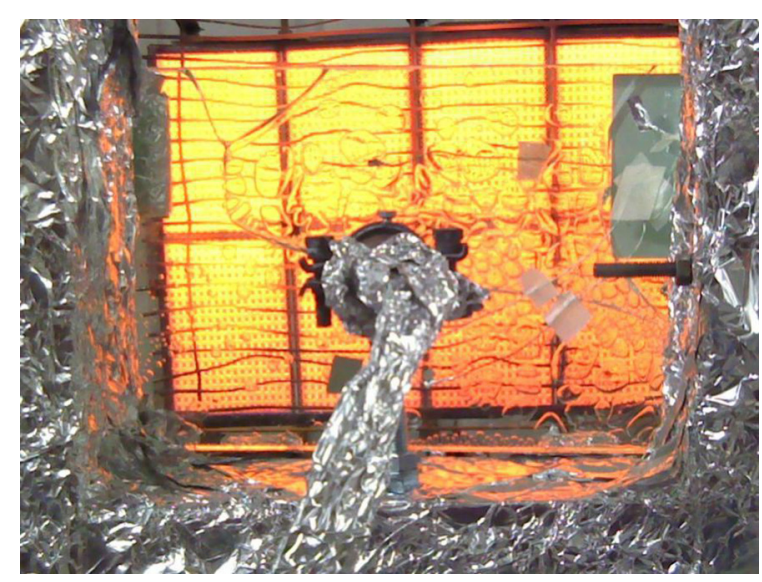

Fig. 14. Testing of a laminated glass panel exposed to a radiant heat flux, as reported in [131]. Note the bubbles forming in the interlayer, as it melts and evaporates. 
(4) the interlayer deforms as a membrane, and

(5) the interlayer fails by reaching its failure strength or by cutting of glass shards.

Literature research efforts focused on the mechanical behavior of laminated glass under blast loading include experimental testing, numerical modeling, analytical derivations.

Despite many field tests were conducted on laminated glass windows, most of these tests were for commercial purposes to assess the performance of particular products, or for military and security purposes. The testing results are therefore not publicly accessible. Kranzer et al. [106] studied the response of laminated glass under small scaled blast load with shock tube. Hooper et al. [107] tested laminated glass windows which failed with interlayer rupture and panel tearing-out from boundary. The accuracies of design codes for laminated glass windows against blast loading were also assessed by several authors, see for example the pressure-impulse curves collected in Fig. 13. Many recent laboratory tests on interlayer materials (see for example $[108,109]$ ), proved that interlayers in use for laminated glazing systems exhibit very different response under dynamic loading, compared to static conditions. Therefore, Single-Degree-Of-Freedom (SDOF) models to analyze the response of laminated glass windows under blast loading (i.e. [12,21]) could highly underestimate laminated glass panel deflections, especially when it is subjected to large scale blast loading (See Fig. 13).

Numerical methods have been also intensively utilized to model the response of laminated glass windows under blast, with extensive application of Finite Element method.

As a general issue of the conventional FE method, reliable approaches in modeling glass under shocks are rare, because of inherited difficulties, especially in terms of glass fragmentation. In addition, careful consideration should be paid for modeling and calibration of single facade components as well as for their reciprocal interactions, including damage models for materials. Larcher et al. [105] assessed the applicability of laminated glass windows modeled with detailed solid element, shell element and smear model, which reported that detailed finite element model with solid element could yield to the best prediction.

Many detailed finite element models of laminated glass windows and mechanically complex glazing assemblies under blast have been generated by various researchers (see for example [108-115]), including also possible solutions to enhance their actual response and resistance. Accurately modeling of glass plies breakage, including major failure phenomena, is still a challenge. As a major issue in numerical modeling, reliable guidelines are still missing [116].

\subsection{Fire}

Ordinary soda-lime glass has in fact practically no fire resistance, which is a serious limitation of its use as a structural material [117]. To overcome this issue, different solutions, e.g. wire netting, stiffening layers or hardening of the glass, are currently available to improve the fire resistance of the basic material. Another way to achieve better fire performance is to use borosilicate glass; however, it is relatively uncommon in structural applications. Various options exist which enhance the insulating properties of laminate glass, for example the use of an intumescent internal layer, which swells when exposed to elevated temperatures, can be used between the glass panes. However this may impact on the integrity of the glass. Another option, is to use transparent intumescent coatings to reduce heat transfer by effectively insulating the exposed surface of the glass [118]; this would have a similar effect to low emissivity coatings which would reduce the effect of heat transfer by radiation. A potential advantage of this solution is that after fires where no damage is caused to the glass material itself, it may be sufficient to replace the coating only.

Existing research on glass facades can be divided into two main groups. The first group of studies relates to the research focused on the behavior of glass in fire on a material and a component level and limits the study until the moment of glass breakage. The second group aims at studies on entire façade systems and the performance of the facade after breakage of a single glass pane. This includes investigation of externally venting flames, double-skin, etc.

Numerous research projects have been carried out to investigate the behavior of glass breakage in fire scenarios. Within these projects special focus has been made to identification of conditions causing glass breakage (temperature gradient), locations of crack initiation, time to first cracking and crack patterns. Various parameters affecting the breakage of glass in fire have been investigated, such as glass type [119-124], boundary constraints [120,121], glass thickness [125-127] and imposed heat flux [120,128-131].

The response of glass facade panels to fire is highly influenced by shadings and constraining conditions [121,125,132,133]. Window glass is usually installed in a frame for fixing to the structure and its edges are shaded by the frame. During fire the exposed regions of the glass pane are heated directly by the fire whereas shaded areas only by thermal conductivity. The temperature difference causes strain at the edge and may lead to premature failure. Wang et al. [134] investigated numerically fire responses of LowE glass facades with different boundary conditions resulting from different installation techniques. Various frame supported glass facades with different constraints configurations were studied. From the results, it was found that shading and constraining conditions significantly influence the breaking performance of glass facades. Panels shaded on four edges break more easily than panels shaded on two opposite sides. Moreover, constrained cases perform better with all edges constrained. Following the numerical studies, the phenomenon was investigated experimentally [135]. It was concluded that Semi-exposed framing glass curtain walls, especially vertical-hidden framing ones, demonstrate greater fire resistance than fully exposed framing façades. Moreover, it was observed that all initial cracks initiated from the frame covered glass edges. Wang et al. [121,136] investigated numerically and experimentally full-scale point-fixed glass facade panes placed at different distance from pool fires. Both float and toughened glasses were investigated. It was found that distance to the fire source has significant effect on the time to the first crack. Moreover, it was concluded that point-supported glass facades have better fire resistance than edge covered glass. Moreover, the performance can be improved by the use of toughened glass. Wang et al. [122] found that clear glass has better fire resistance than coated glass.

Wang et al. [123] investigated the thermal performance of double glazing under fire conditions. It was concluded that the first crack in a double glazing system is usually initiated in Pane 1, and fire performance of Pane 2 is strictly related to the performance of Pane 1 . Moreover, different installation cases significantly affect the fire response of double glazing units, but the influence is primarily limited to Pane 1 . In addition, the thickness of any air cavity gap affects the thermal response of doubleglazed units, but the influence is primarily limited to Pane 2. Wang et al. [124] conducted a series of full-scale experiments to investigate the breakage behavior of single coated, insulated and laminated glass heated by a $500 \times 500 \mathrm{~mm}^{2}$ pool fire. Numerical simulations were also performed to investigate and compare the heat transfer mechanisms in these glasses. It was found that the insulated and laminated glass can survive longer than the single glass. The air gap and fire side glass pane was found to play a key role for the thermal resistance of ambient side panes in the insulated glazing. Although both panes of the laminated glazing 
broke, it could be held together by the layer of gel, effectively avoiding the formation of a new vent.

Debuyser et al. [131] studied the heat transfer through laminate and monolithic glass; he characterised the transmissivity of glass based on different interlayers and build ups of the different lamella (see Fig. 14). In summary, for radiative heat transfer, the fraction of the heat flux absorbed in the different samples tested was between $58 \%$ and $88 \%$ of the total heat flux in samples without a low emissivity coating; depending on the build up and the interlayer. The rest is either transmitted or reflected. In samples with a low emissivity coating, the reflected fraction of the heat flux was over $60 \%$. The authors also developed a simple numerical heat transfer model based on experiments in which several monolithic and laminated glass configurations were exposed to a radiant heat flux. The model is able to determine the evolution of the temperature profile as a result of a given incident heat flux.

A number of issues surrounding the use of load bearing glass in buildings being designed for fire, and the need to consider the response of load bearing glass as part of the overall fire strategy was discussed by Sjöström et al. [137].

When combustible materials are installed on the building facade externally venting flames may increase the risk of fire spreading to higher floors or adjacent building [138]. Similar phenomenon may occur when a fire initiates in the interior space of a building causing failure of glass panes in windows and form compartment opening. Asimakopoulou et al. [139] investigated the fundamental thermal phenomena governing externally venting flames development and their impact on façade systems in an experimental campaign including a medium- and a large-scale compartment-façade fire test.

Chow et al. [140] performed fire tests on glass facade panels with a special focus on the heat transferred from the fire room and smoke movement in the glass façade model measured by thermocouples installed in the air gap between the two glass panes. The glass panes were heated up to $45^{\circ} \mathrm{C}$ to include solar heating effects. Within the same research project fire response of a single glass panes directly exposed to flames coming out of the fire chamber were studied. Locations of cracks and time to cracking were measured. Chow [141] performed experimental and numerical studies on the consequence of the fire hazard due to trapping heat and mass in the cavity of double-skin facades. He investigated a rig of $15 \mathrm{~m}$ height and cavity depths of $1,1.5$ and $2.5 \mathrm{~m}$. The same phenomenon was the topic of studies by Junmai et al. [142] and Peng et al. [143].

Although some experimental work on glass panes has been reported in the literature, as partly summarized above, very few studies are related to the entire façade system. Chow et al. [144] performed a full-scale burning testing program on a facade mock-up tested earlier for wind action and water penetration. The facade was $12 \mathrm{~m}$ in length and $13 \mathrm{~m}$ high, it consisted of double-glazed panes $1.5 \times 3 \mathrm{~m}$. A panel of the ground level was removed and replaced with a fire chamber placed inside. The research investigated the behavior of flame moves out of the fire room and spreads up the glass facade.

\subsection{Climatic events}

Climate changes and related impact on structural safety of constructed facilities in general is attracting continuously increasing interest [145].

Research studies have been for example carried out to assess the typical stress distribution and response of glass windows, in presence of several loading scenarios due to wind pressure or localized impacts, i.e. [146-150].

In the case of glazing facades and curtains (even not composed of glass panels), careful consideration should be paid for full assemblies but also to single cladding components. Nečasová et al. [151], for example, experimentally assessed the adhesion and cohesion properties of silicone sealants in use for curtain walls, giving evidence of the effects of extreme temperatures $\left(-20^{\circ} \mathrm{C}\right.$ up to $70^{\circ} \mathrm{C}$ the range of interest).

Full-scale testing has a fundamental role in design and verification of glass claddings under climatic events or specific weather conditions [152]. Ilter et al. [153] made tests to understand longterm environmental impacts on glazing curtain wall systems. A comparative analysis of the structural and infiltration performance of two identically detailed and produced unitized curtain wall system mock-ups was presented. Fatigue loading conditions were also imposed, in addition to standard test procedures, giving evidence of performances losses due to air infiltrations or wind pressures. Kaskel et al. [154] critically reviewed current regulations given by standards for testing the water penetration and leakage performance of curtain walls.

Several research studies are also available in the literature for assessing the structural response of glass curtains of specific typologies, under the effect of wind loads. Most of these contributions report on the dynamic performance of advanced glazing systems, i.e. cable supported facades, whose structural behavior requires enhanced detailing, compared to framed curtain systems. As a results, ordinary wind pressures are mainly accounted only, as also in accordance with current design provisions. Yu et al. [155], for example, investigated via numerical models the overall performance of a L-shaped cable-supported facade under assigned wind loads. In their research study, fluid-structures interaction was considered, including statistical analysis of measured effects in the facade components (i.e. maximum displacements, accelerations and stresses in glass and supporting cables). Wind effects on point-supported glass panels belonging to a curtain wall were also numerically investigated in [156], giving evidence of major criticalities for safety design purposes. Aurelius and Rofail [157] presented two alternative methods to determine the net pressure wind loads on the inter-tenancy walls within a tall building with an operable façade. In [158], in order to determine the wind loads on a doubleskin facade with no-leakage air barrier and to predict the load difference between double-skin or single-skin facades, wind tunnel tests on a cylindrical and a rectangular tall building with arcshape and L-shape curtains have been respectively carried out. The research investigation of Mitsos et al. [159] focused on a new concept of double-layer tensegrity glazing system. A computational analysis was carried out, assessing the actual performance of such tensegrity facades under wind loads and temperature changes. Meinen et al. [160] assessed a probabilistic procedure for wind-loaded façade elements, giving evidence to what extent wind-loaded façade elements fulfill the minimum reliability requirements given by Eurocodes.

\section{Conclusions}

In this review paper, a state of the art on glass facades under extreme loading conditions was presented, with emphasis for available design methods and requirements, as well as existing research on the topic. Careful consideration was paid both for natural hazards and accidental or human induced (external) explosions, giving evidence - despite the huge difference in the intrinsic features of investigated loading conditions - of expected effects and related issues.

As a general rule, appropriate safety levels have in fact to be offered to typically vulnerable glazing envelopes and curtain walls. In this context, the paper highlighted that in most of the cases specific design regulations are missing for glazing facades. At the same time, high strain loads and displacements should be properly 
sustained and accommodated by glazing systems, as a part of a full 3D building they belong. The occurrence of an increasing number of natural hazards and tragic events, in this sense, attracted the interest of several researchers, which over the past years assessed experimentally, numerically and analytically the specific response of specific glass curtains aspects, when subjected to extreme loads. Further efforts are however required, towards the full exploration and implementation of general safety rules for such systems.

\section{Acknowledgments}

The ongoing EU-COST Action TU1043 "Adaptive Facades Network" (2014-2018, www.tu1403.eu) and the "International Association of Protective Structures" (IAPS, www.protectivestructures.org) are gratefully acknowledged for facilitating networking between the involved authors.

\section{References}

[1] M. Haldimann, A. Luible, M. Overend, "Structural Use of Glass", IABSE International Association for Bridge and Structural Engineering, 2008, ISBN 978-3-85748-119-2.

[2] M. Feldmann, R. Kasper, B. Abeln, P. Cruz, J. Belis, J. Beyer, et al., “Guidance for European Structural design of glass components - support to the implementation, harmonization and further development of the Eurocodes", Report EUR 26439, Joint Research Centre-Institute for the Protection and Security of the Citizen, doi: 10.2788/5523, Pinto Dimova, Denton Feldmann (Eds.), 2014.

[3] ASTM C1048. Standard Specification for Heat-Treated Flat Glass-Kind HS, Kind FT Coated and Uncoated Glass. ASTM International, West Conshohocken, PA, 1997, www.astm.org.

[4] M.M. Chaudhri, C. Liangyi, The catastrophic failure of thermally tempered glass caused by small-particle impact, Nature 320 (1986) 48-50.

[5] X. Zhang, H. Hao, Z. Wang, Experimental investigation of monolithic tempered glass fragment characteristics subjected to blast loads, Eng. Struct. 75 (2004) 259-275.

[6] X. Zhang, H. Hao, Z. Wang, Experimental investigation on monolithic tempered glass window responses to blast loads, Int. J. Protect. Struct. 6 (2015) 287-309.

[7] J.M. Barsom, Fracture of tempered glass, J. Am. Ceram. Soc. 51 (1968) 75-78.

[8] M. Overend, G. Parke, D. Buhagiar, Predicting failure in glass-a general crack growth model, J. Struct. Eng. 133 (2007) 1146-1155.

[9] A.A. Griffith, "The phenomena of rupture and flow in solids", Philosophical transactions of the Royal Society of London. Series A, containing papers of a mathematical or physical character, 221: pp. 163-198, 1921.

[10] pr-EN 13474-3:2009. Glass in Buildings - Determination of the Strength of Glass Panes - Part 3: General Method of Calculation and Determination of Strength of Glass by Testing, European Committee for Standardisation (CEN), Brussels, Belgium.

[11] X. Zhang, Y. Zou, H. Hao, X. Li, G. Ma, K. Liu, Laboratory test on dynamic material properties of annealed float glass, Int. J. Protect. Struct. 3 (2012) 407-430.

[12] C. Morison, "The resistance of laminated glass to blast pressure loading and the coefficients for single degree of freedom analysis of laminated glass", $\mathrm{Ph}$ D. Dissertation, Cranfield University (UK), 2010, http://dspace.lib.cranfield.ac. uk/handle/1826/4651.

[13] M.G. Stewart, M.D. Netherton, Security risks and probabilistic risk assessment of glazing subject to explosive blast loading, Reliab. Eng. Syst. Safety 93 (2008) 627-638.

[14] W.L. Beason, J.R. Morgan, Glass failure prediction model, J. Struct. Eng. 110 (2008) 197-212.

[15] M. Overend, K. Zammit, A computer algorithm for determining the tensile strength of float glass, Eng. Struct. 45 (2012) 68-77.

[16] W.L. Beason, "A failure prediction model for window glass", Ph.D. Dissertation, Texas Tech University, https://ttu-ir.tdl.org/ttu-ir/handle/2346/ 10495, 1980.

[17] ASTM, E-1300-09. Determining load resistance of glass in buildings. ASTM International, West Conshohocken, PA, 2009, www.astm.org.

[18] I. Nurhuda, N. Lam, E. Gad, I. Calderone, Estimation of strengths in large annealed glass panels, Int. J. Solids Struct. 47 (2010) 2591-2599.

[19] D.Z. Yankelevsky, Strength prediction of annealed glass plates - a new model, Eng. Struct. 79 (2014) 244-255.

[20] prEN 13474-1:1999. Glass in Buildings - Design of Glass Panes - Part 1 General Basis of Design, European Committee for Standardisation (CEN), Brussels, Belgium.

[21] X. Zhang, H. Hao, The response of glass window systems to blast loadings: an overview, Int. J. Protect. Struct. 7 (2016) 123-154.

[22] G.R. Johnson, T.J. Holmquist, “An improved computational constitutive model for brittle materials", AIP Conference Proceedings, 309, 1994
[23] M. Peroni, G. Solomos, V. Pizzinato, M. Larcher, Experimental investigation of high strain-rate behaviour of glass, Appl. Mechan. Mater. 82 (2011) 63-68.

[24] W.G. Brown, "A practicable formulation for the strength of glass and its special application to large plates", Publication number NRC 14372, National Research Council of Canada Ottawa, 1974.

[25] EN 572-1:2012. Glass in buildings: Basis soda lime silicate glass products definitions and general physical and mechanical properties, European Committee for Standardisation (CEN), Brussels, Belgium.

[26] S.G. Reid, "Model Errors in the Failure Prediction Model of Glass Strength", Proceedings of 8th ASCE Specialty Conference on Probabilistic Mechanics and Structural Reliability, Alberta, Canada, 2000.

[27] M. Overend, “Glass”, ICE Manual of Structural Design, ICE Publishing, 2012. ISBN: 978-0-7277-4144-8.

[28] COST TU0601 - Structural Robustness Design for Practising Engineers, T.D.G. Canisius (Editor), 2011, www.costtu0601.ethz.ch.

[29] D. Honfi, M. Overend, "Glass structures - learning from experts", Proceedings of COST Action TU0905 - Mid-term Conference on Structural Glass, Porec, Croatia, 2013.

[30] F.P. Bos, "Safety Concepts in Structural Glass Engineering - Towards an Integrated approach", Ph.D. Dissertation, TU Delft, https://repository.tudelft. nl/islandora/object/uuid:85191798-a57d-4be0-a0c0-7096dc2976fe ?collection=research, 2009.

[31] EN 1991-1:2005. Eurocode 1 - Actions on structures, European Committee for Standardisation (CEN), Brussels, Belgium.

[32] I. Mohagheghian, Y. Wang, J. Zou, L. Yu, X. Guo, Y. Yan, M.N. Charalambides, J. P. Dear, Deformation and damage mechanisms of laminated glass windows subjected to high velocity soft impact, Int. J. Solids Struct. 109 (2017) 46-62.

[33] R. Kalamar, C. Bedon, M. Eliášová, Assessing the structural behaviour of square hollow glass columns subjected to combined compressive and impact loads via full-scale experiments, Eng. Struct. 143 (2017) 127-140.

[34] L.C. Forde, W.G. Proud, S.M. Walley, P.D. Church, I.G. Cullis, Ballistic impact studies of a borosilicate glass, Int. J. Impact Eng. 37 (5) (2010) 568-578.

[35] P. Jannotti, B. Aydelotte, B. Schuster, "Time-Resolved Terminal Ballistic Response of Glass", Proceedings of 29th ISB - International Symposium on Ballistics, Edinburgh, Scotland, 9-13 May, 2016.

[36] G.-I. Shim, S.-H. Kim, H.-W. Eom, D.-L. Ahn, J.-K. Park, S.-Y. Choi, Improvement in ballistic impact resistance of a transparent bulletproof material laminated with strengthened soda-lime silicate glass, Compos. Part B 77 (2017) 169178.

[37] M.L. Wang, Cladding performance on a full-scale test frame, Earthquake Spectra 3 (1) (1987) 119-173.

[38] EN 1998-1-1:2004. Eurocode 8 - Design of structures for earthquake resistance - Part 1: General rules, seismic actions and rules for buildings, European Committee for Standardisation (CEN), Brussels, Belgium.

[39] NZS 1170.5:2004. Structural Design Actions - Part 5, ZEALAND, STANDARDS NEW, Wellington, NZ.

[40] FEMA 450:2003. Recommended provisions for seismic regulations for new buildings and other structures.

[41] AAMA - American Architectural Manufacturers Association, "Recommended static test method for evaluating curtain wall and storefront systems subjected to seismic and wind induced interstory drifts", Publication No. AAMA 501.4-01, 2001.

[42] AAMA - American Architectural Manufacturers Association, "Recommended dynamic test method for determining the seismic drift causing glass fallout from a wall system", Publication No. AAMA 501.6-01, 2001.

[43] UFC 3-340-02:2008. Structures to Resist the Effects of Accidental Explosions, US DoD, Washington, DC, US.

[44] V. Karlos, G. Solomos, "Calculation of blast loads for application to structural components", Administrative Arrangement N JRC 32253-2011 with DGHome - Activity A5 - Blast Simulation Technology Development, Technical Report, 2013, freely available online at (last access: July 2017): http:/| publications.jrc.ec.europa.eu/repository/bitstream/JRC87200/lbna26456enn. pdf.

[45] GSA TS-01:2003. Standard Test Method for Glazing and Window Systems Subject to Dynamic Overpressure Loadings, General Services Administration, US.

[46] ASTM F1642:2004. Standard Test Method for Glazing and Glazing Systems subject to Air Blast Loadings, West Conshohocken, PA, US.

[47] ISO 16933:2007. Explosion-Resistant Security Glazing- Test and Classification for Arena Air-Blast Loading, International Organization for Standardization (ISO).

[48] HOSDB, 1997. Special Services Group, Explosion Protection. Glazing Hazard Guide-Charts, Security Facilities Executive; Report SSG/EP/3/97; Cabinet Office (Home Office Scientific Development Branch), London, UK.

[49] Meyer, S., Little, L., Conrath, E., 2004. Injury Based Glass Hazard Assessment DTIC Document, freely available online at (last access: July 2017): http:// www.dtic.mil/dtic/tr/fulltext/u2/a548169.pdf.

[50] D. Lange, "A review of blast loading and explosions in the context of multifunctional buildings", SP Arbetsrapporter NV-2013:11, Brandmotstånd, SP Fire Research, SP-Sveriges Tekniska Forskningsinstitut, RISE, 2013.

[51] UFC 4-010-01:2012. Minimum Antiterrorism Standards for Buildings, US Department of Defence.

[52] S. Colwell, T. Baker, "Fire performance of external thermal insulation for walls of multi-storey buildings", 3rd Edition, 2013, ISBN 978-1-84806-234-4.

[53] European Parliament - Regulation (EU) No. 305/2011 of the European Parliament and of the Council of 9 March 2011 laying down harmonised 
conditions for the marketing of construction products and repealing Council Directive 89/106/EEC, Official Journal of the European Union, 88: pp. 5-43. 2011.

[54] EN 13501-1:2002. Fire classification of construction products and building elements - Part 1: Classification using test data from reaction to fire tests, European Committee for Standardisation (CEN), Brussels, Belgium.

[55] EN 13823:2002. Reaction to fire tests for building products. Building products excluding floorings exposed to the thermal attack by a single burning item, European Committee for Standardisation (CEN), Brussels, Belgium.

[56] CWCT - Centre for Window and Cladding Technology, "Fire performance of facades - Guide to the requirements of UK Building Regulations", Technical Note 98, 2007, http://www.cwct.co.uk/CWCT-TN98-Fireandfacades.pdf.

[57] European Commission - 96/603/EC: Commission Decision of 4 October 1996 establishing the list of products belonging to Classes A 'No contribution to fire' provided for in Decision 94/611/EC implementing Article 20 of Council Directive 89/106/EEC on construction products, 1996.

[58] L. Boström, R. Chiva, S. Colwell, I. Móder, A. Hofmann, D. Lange, J. Anderson, "Development of a European approach to assess the fire performance of facades", Progress Report, Project: SI2.743702-30-CE-0830933/00-14.

[59] BS 8414-1:2015. Fire performance of external cladding systems. Test method for non-load bearing external cladding systems applied to the masonry face of a building, British Standards Institution (BSI), London, United Kingdom.

[60] BS 8414-2:2015. Fire performance of external cladding systems. Test method for non-load bearing external cladding systems fixed to and supported by a structural steel frame, British Standards Institution (BSI), London, United Kingdom.

[61] SP FIRE 105. Method for fire testing of façade materials, Dnr 171-79-360. Department of Fire Technology, Swedish National Testing and Research Institute, 1985.

[62] DIN 4102. Fire behaviour of building materials and building components Part 20: Particular verification of the fire behavior of cladding for external walls.

[63] A. Bajić, Bora wind load upon structures, Croatian Meteorol. J. 48 (49) (2015) $3-17$.

[64] V. Divic, “Croatian building regulations concerning wind loading”, Presentation given during WindRisk Workshop, 10th September, 2015, http://www.windrisk.eu.

[65] W.L. Beason, G.E. Meyers, R.W. James, Hurricane related window glass damage in Houston, J. Struct. Eng. 110 (12) (1984) 2843-2857.

[66] J.E. Minor, Lessons learned from failures of the building envelope in windstorms, J. Architect. Eng. 11 (1) (2005) 10-13.

[67] C.-H. Wang, X. Wang, Y.B. Khoo, Extreme wind gust hazard in Australia and its sensitivity to climate change, Nat. Hazards 67 (2) (2013) 549-567.

[68] S.C. Pryor, R. Conrick, C. Miller, J. Tytell, R.J. Barthelmie, "Intense and extreme wind speeds observed by anemometer and seismic networks: an Eastern U.S. case study", AMS Journals Online, American Meteorological Society, https://doi.org/10.1175/JAMC-D-14-0091.1, 2014.

[69] C.P. Konrad, "Effects of Urban Development on Floods", USGS Fact Sheet 07603, US Geological Survey.

[70] FEMA P-1037. Reducing flood risk to residential buildings that cannot be elevated, 2015.

[71] J. Torti, Floods in Southeast Asia: a health priority, J. Global Health 2 (2) (2012) 020204.

[72] C.S. Cheng, J.C. Tong, Building Sustainability in East Asia: Policy, Design and People, John Wiley \& Sons Ltd, 2017.

[73] UN-ESCAP, "Disasters in Asia and the Pacific: 2015 Year in Review”, United Nations, Economic and Social Commission for Asia and Pacific, 2016.

[74] European Investment Bank, "Guide for preparation of flood risk management schemes”, Document MCR4100, 2008, http://www.eib.org.

[75] English Heritage, "Flooding and Historic Buildings", 2010, www.englishheritage.org-uk.

[76] L. Alfieri, J. Thielen, A European precipitation index for extreme rain-storm and flash flood early warning, Meteorol. Appl. 22 (2012) 3-13, https://doi. org/10.1002/met.1328.

[77] R.A. Behr, Design of architectural glazing to resist earthquakes, J. Architect. Eng. 12 (3) (2006) 122-128.

[78] D. Ding, C. Arnold, H. Lagorio, S. Tobriner, S. Rihal, R. Mangum, G, Hezmalhalch, M. Green, A. Watson, D. Mah, B. Metro, J. Podany, R. Sharpe, Architecture, building, contents, and building systems, Earthquake Spectra 6 (S1) (1990) 339-377.

[79] EERI - Earthquake Engineering Research Institute, "Loma Prieta Earthquake reconnaissance report", Earthquake Spectra, Supplement to Volume 6, Oakland, Calif., 1990.

[80] EERI - Earthquake Engineering Research Institute, “Northridge Earthquake reconnaissance report" (CD Rom), Earthquake Spectra, Supplement to Volume 11, 1995.

[81] EERI - Earthquake Engineering Research Institute, "The Hyogo-Ken Nanbu (Kobe) Earthquake, January 17, 1995 - Preliminary Reconnaissance Report”, 1995.

[82] EERI - Earthquake Engineering Research Institute, "Nisqually, Washington Earthquake of February 28, 2001 - Preliminary Reconnaissance Report", 2001.

[83] B. Reitherman, T. Sabol, R. Bachman, D. Bellet, R. Bogen, D. Cheu, P. Coleman, J. Denney, M. Durkin, C. Fitch, R. Fleming, W. Gates, B. Goodno, M. Halling, R. Hess, Nonstructural damage, Earthquake Spectra 11 (S2) (1945) 453-514.
[84] NE03 - NEHRP (2003) National Earthquake Hazard Reduction Program Recommended Provisions for Seismic Regulations for Buildings and Other Structures, Federal Emergency Management Agency, Washington, DC.

[85] N. Caterino, M. Del Zoppo, G. Maddaloni, A. Bonati, G. Cavanna, A. Occhiuzzi, Seismic assessment and finite element modelling of glazed curtain walls, Struct. Eng. Mech. 61 (1) (2017) 77-90.

[86] J.G. Bouwkamp, J.F. Meehan, "Drift Limitations Imposed by Glass", Proceedings of the Second World Conference on Earthquake Engineering, Tokyo, pp. 1763-1778, 1960

[87] CU85 - Cupples (1985) "Curtain Wall Tests for Cupples Horizon Series of World Wall." Cupples test report No. STL-33, St. Louis, MO.

[88] K. Lim, A.B. King, "The Behavior of External Glass Systems Under Seismic InPlane Racking", Building Research Association of New Zealand (BRANZ) Study Report, No.39, 1991.

[89] H. Sucuoglu, C.V.G. Vallabhan, Behaviour of window glass panels during earthquakes, Eng. Struct. 19 (8) (1997) 685-694.

[90] R.A. Behr, A. Belarbi, J.H. Culp, Dynamic racking tests of curtain wall glass elements with in-plane and out-of-plane motions, Earthquake Eng. Struct. Dyn. 24 (1) (1995) 1-14.

[91] A. Memari, R.A. Behr, P.A. Kremer, Seismic behavior of curtain walls containing insulating glass units, J. Archit. Eng. 9 (2) (2003) 70-85.

[92] A. Memari, R.A. Behr, P.A. Kremer, Dynamic racking crescendo tests on architectural glass fitted with anchored pet film, J. Archit. Eng. 10 (1) (2004) $5-14$.

[93] A. Memari, P.A. Kremer, R.A. Behr, Architectural glass panels with rounded corners to mitigate earthquake damage, Earthquake Spectra 22 (1) (2006) $129-150$.

[94] FEMA 450:2003, Recommended provisions for seismic regulations for new buildings and other structures, FEMA.

[95] AS02 - ASCE. (2002). "Minimum design loads for buildings and other structures." ASCE 7-02, Reston, Va.

[96] IB02 - International Code Council (ICC). (2002). International building code (IBC) 2003, Country Club Hills, Ill.

[97] J.L. Brueggeman, R.A. Behr, H. Wulfer, A. Memari, P.A. Kremer, Dynamic racking performance of an earthquake-isolated curtain wall system, Earthquake Spectra 16 (4) (2000) 735-756.

[98] E.B. Philip, "Blast and The Ministry of Home Security", Research and Expeirments Department, 1939-1945. Report No. REN 585, Ministry of Home Security, 1945.

[99] D. Pritchard, Breakage of glass windows by explosions, J. Occup. Accidents 3 (2) (1981) 69-85.

[100] X. Zhang, C. Bedon, "Vulnerability and protection of glass windows and facades under blast: experiments, methods and current trends", Internationa Journal of Structural Glass and Advanced Materials Research, published online, http://thescipub.com/abstract/10.3844/ofsp.11359, 2017.

[101] J. Ge, G.-Q. Li, S.-W. Chen, Theoretical and experimental investigation on fragment behavior of architectural glass panel under blast loading, Eng. Failure Anal. 26 (2012) 293-303.

[102] A. van Doormaal, J. Weerheijm, M. Rhijnsburger, “Hazard of glazing due to blast loading", Proceedings of the International Symposium on Interaction of the Effects of Munitions with Structures, Florida, USA, 2009 (CD Rom)

[103] E.R. Fletcher, D.R. Richmond, J.T. Yelverton, “Glass fragment hazard from windows broken by airblast", DTIC Document, 1980, freely available online at (last access: July 2017): http://oai.dtic.mil/oai/oai?verb=getRecord\& metadataPrefix =html\&identifier=ADA105824.

[104] J.H. Iverson, "Summary of Existing Structures Evaluation Part II: Window Glass and Applications". Office of Civil Defense; Office of the Secretary of the Army, 1968.

[105] M. Larcher, G. Solomos, F. Casadei, N. Gebbeken, Experimental and numerica investigations of laminated glass subjected to blast loading, Int. J. Impact Eng. 39 (1) (2012) 42-50.

[106] C. Kranzer, G. Gürke, C. Mayrhofer, "Testing of Bomb Resistant Glazing Systems-Experimental Investigation of the Time Dependent Deflection of Blast Loaded $7.5 \mathrm{~mm}$ Laminated Glass", Proceedings of Glass Processing Days, Tampere, Finland, 2005.

[107] P.A. Hooper, R.A.M. Sukhram, B.R.K. Blackman, J.P. Dear, On the blast resistance of laminated glass, Int. J. Solids Struct. 49 (6) (2012) 899-918.

[108] X. Zhang, H. Hao, Y. Shi, J. Cui, The mechanical properties of Polyvinyl Butyral (PVB) at high strain rates, Constr. Build. Mater. 93 (2015) 404-415.

[109] X. Zhang, Y. Shi, H. Hao, J. Cui, The mechanical properties of ionoplast interlayer material at high strain rates, Mater. Des. 83 (2015) 387-399.

[110] C. Bedon, C. Amadio, Passive control systems for the blast enhancement of glazing curtain walls under explosive loads, Open Civ. Eng. J. 10 (2017) 3-26.

[111] H.D. Hidallana-Gamage, D. Thambiratnam, N. Perera, Numerical modelling and analysis of the blast performance of laminated glass panels and the influence of material parameters, Eng. Failure Anal. 45 (2014) 65-84.

[112] J. Nakhaei, S. Forghani, M. Bitarafan, S.L. Arefi, J. Saparauskas, Reinforcement of laminated glass facades against the blast load, J. Civ. Eng. Manage. 21 (8) (2015) 1085-1097.

[113] M. Nawar, H. Salim, B. Lusk, S. Kiger, Modelling and shock tube testing of architectural glazing systems for blast resistance, J. Struct. Eng. 141 (7) (2015), https://doi.org/10.1061/(ASCE)ST.1943-541X.0001130.

[114] J. Pelfrene, S.Van Dam, W. Van Paepegem, "Simulating dynamic glass fracture in an air blast event", Proceedings of 13th FEA PhD Symposium, 2012. 
[115] M. Zobec, G. Lori, R. Lumantarna, T. Ngo, C. Nguyen, Innovative design tool for the optimization of blast-enhanced facade systems, J. Facade Des. Eng. 2 (34) (2014) 183-200.

[116] M. Larcher, M. Arrigoni, C. Bedon, A. van Doormaal, C. Haberacker, G. Hüsken, O. Millon, A. Saarenheimo, G. Solomos, L. Thamie, G. Valsamos, A. Williams, A. Stolz, Design of blast-loaded glazing windows and facades: a review of essential requirements towards standardization, Adv. Civ. Eng. (2016) 14, https://doi.org/10.1155/2016/2604232, 2016.

[117] L. Boström, "Ageing Effects on the Fire Resistance of Building Structures", Brandforsk Project 322-011. 322. SP Swedish National Testing and Research Institute, Borås, Sweden, 2002.

[118] F.A. Veer, M. van der Voorden, M. Rijgersberg, J. Zuidema, “Using transparent intumescent coatings to increase the fire resistance of glass and glass laminates", Proceedings of Glass processing days, Tampere, Finland, 18-21 June, 2001.

[119] S.K.S. Hassani, J. Shields, G.W. Silcock, An experimental investigation into the behaviour of glazing in enclosure fire, J. Appl. Fire Sci. 4 (4) (1994) 303-323.

[120] K. Harada, A. Enomoto, K. Uede, T. Wakamatsu, "An experimental study on glass cracking and fallout by radiant heat exposure", Proceedings of the 6th International Symposium Fire Safety Science, University of Poitiers, France, IAFSS, pp. 1063-1074, doi:10.3801/IAFSS.FSS.6-1063, 2000.

[121] Y. Wang, Q. Wang, G. Shao, H. Chen, Y. Su, J. Sun, L. He, J.X. Wen, R. Zong, K.M. Liew. "Experimental Study on Thermal Breakage of Four-Point Fixed Glass Façade", Proceedings of the 11th International Symposium Fire Safety Science, pp. 666-676, DOI: 10.3801/IAFSS.FSS.11-666.

[122] Y. Wang, O. Wang, J. Sun, L. He, K.M. Liew, Thermal performance of exposed framing glass facade in fire, Mater. Struct. 47 (7) (2016) 2961-2970.

[123] Y. Wang, Q. Wang, Y. Su, J. Sun, L. He, K.M. Liew, Experimental study on fire response of double glazed panels in curtain walls, Fire Safety J. 92 (2017) 5363.

[124] Y. Wang, Q. Wang, J.X. Wen, J. Sun, K.M. Liew, Investigation of thermal breakage and heat transfer in single, insulated and laminated glazing under fire conditions, Appl. Therm. Eng. 125 (2017) 662-672.

[125] I. Khanina, C. Vergara, Y.P. He, "Window glass breakage in fires”, Proceedings of the 7th Australian Heat and Mass Transfer Conference, Townsville, pp. $187-193,2000$

[126] Y. Zhang, Q.S. Wang, X.B. Zhu, X.J. Huang, J.H. Sun, Experimental study on crack of float glass with different thicknesses exposed to radiant heating, Proc. Eng. 11 (2011) 710-718.

[127] L.M. Li, O.Y. Xie, X.D. Cheng, H.P. Zhang, Cracking behavior of glazings with different thicknesses by radiant exposure, Fire Mater. 36 (4) (2011) 264-276.

[128] T.J. Shields, G.W.H. Silcock, M.F. Flood, Performance of a single glazing assembly exposed to enclosure corner fires of increasing severity, Fire Mater 25 (4) (2011) 123-152.

[129] T.J. Shields, G.W.H. Silcock, M.F. Flood, Performance of a single glazing assembly exposed to a fire in the centre of an enclosure, Fire Mater. 26 (2) (2002) 51-75.

[130] T.J. Shields, G.W.H. Silcock, M.F. Flood, Behaviour of double glazing in corner fires, Fire Technol. 41 (1) (2005) 37-65.

[131] M. Debuyser, J. Sjöström, D. Lange, D. Honfi, D. Sonck, J. Belis, Behaviour of monolithic and laminated glass exposed to radiant heating, Constr. Build. Mater. 130 (2017) 212-229.

[132] M.J. Skelly, R.J. Roby, C.L. Beyler, An experimental investigation of glass breakage in compartment fires, J. Fire Protect. Eng. 3 (1) (1991) 25-34.

[133] H. Chen, Q. Wang, Y. Wang, H. Zhao, J. Sun, L. He, Experimental and numerical study of window glass breakage with varying shaded widths under thermal loading, Fire Technol. 53 (1) (2017) 43-46.

[134] Y. Wang, Y. Wu, Q. Wang, K.M. Liew, H. Chen, J. Sun, L. He, Numerical study on fire response of glass facades in different installation forms, Constr. Build. Mater. 61 (2014) 172-180.

[135] Y. Wang, O. Wang, Y. Su, J. Sun, L. He, K.M. Liew, Fracture behavior of framing coated glass curtain walls under fire conditions, Fire Safety J. 75 (2015) 4558.

[136] Y. Wang, Q. Wang, J. Sun, L. He, K.M. Liew, Influence of fire location on the thermal performance of glass façades, Appl. Therm. Eng. 106 (2016) 438-442.

[137] J. Sjöström, D. Lange, M. Debuyser, D. Honfi, D. Sonck, J. Belis, “Application of concepts of fire resistance of load bearing structural glass", Proceedings of SiF 2016 - 9th International Conference on Structures in Fire, Princeton, 8-10 June, 2016
[138] J. Sun, L. Hu, Y. Zhang, A review on research of fire dynamics in high-rise buildings, Theor. Appl. Mech. Lett. 3 (4) (2013).

[139] E.K. Asimakopoulou, D.I. Kolaitis, M.A. Founti, Thermal characteristics of externally venting flames and their effect on the exposed façade surface, Fire Safety J. 91 (2017) 451-1160.

[140] W.K. Chow, Y. Gao, H. Dong, G.W. Zou, S.S. Han, C.L. Chow, Experimental studies on fire response of glass façade systems, Int. J. Eng. Perform.-Based Fire Codes 8 (2) (2006) 54-68.

[141] C.L. Chow, "A qualitative investigation on double-skin façade fires", Proceedings of the 1st International Seminar for Fire Safety of Facades, MATEC Web of Conferences Vol. 9, November 14-15, Paris, France. Article number 03007, DOI: 10.1051/matecconf/20130903007, 2013.

[142] J. Li, X. Xing, C. Hu, Y. Li, C. Yin, S. Liu, Numerical studies on effects of cavity width on smoke spread in double-skin facade, Proc. Eng. 45 (2012) 695-699.

[143] L. Peng, Z. Ni, and X. Huang, "Experimental and numerical study of fire spread upon double-skin glass facades", Proceedings of 1st International Seminar of Fire Safety of Facades, MATEC Web of Conferences, Vol. 9, November 14-15, Paris, France, Article number 03009, 2013, DOI: 10.1051/matecconf/ 20130903009.

[144] W.K. Chow, S.S. Han, C.L. Chow, A. So, Experimental measurement on air temperature in a glass façade fire, Int. J. Eng. Perform.-Based Fire Codes 9 (2) (2007) 78-86.

[145] R.D.J.M. Steenbergen, C.P.W. Geurts, C.A. van Bentum, Climate change and its impact on structural safety, Heron 1 (54) (2009) 3-37.

[146] J.E. Minor, "Analysis of the window damaging mechanism in windstorms", Ph.D. Dissertation, Texas Tech University, Lubbock, Tex, USA, 1974.

[147] C.V.S. Kameswara, Rao, "Safety of glass panels against wind loads", Eng. Struct. 6 (3) (1984) 232-234.

[148] C.V G. Vallabhan, G.D. Chou, "Stresses and displacements of window glass due to wind", Proceedings of 5th US National Conference on Wind Engineering, Texas Tech University, Lubbock, Tex, USA, 1985.

[149] E. Gavanski, G.A. Kopp, Glass breakage tests under fluctuating wind loads, J. Architect. Eng. 17 (1) (2011), https://doi.org/10.1061/(ASCE)AE.19435568.0000028.

[150] M.S. Shetty, L.R. Dharani, D.S. Stutts, “Analysis of Laminated Architectural Glazing Subjected to Wind Load and Windborne Debris Impact", ISRN Civil Engineering, vol. 2012, Article ID 949070, 9 pages, 2012. doi:10.5402/2012/ 949070.

[151] B. Nečasová, P. Liška, M. Šimačková, J. Šlanhof, Test of adhesion and cohesion of silicone sealants on facade cladding materials within extreme weather conditions, Adv. Mater. Res. 23-26 (2014) 1041.

[152] M.D. Gonçalves, R. Jutras, "Evaluating the field performance of windows and curtain walls of large buildings", Proceedings of BEST2 Conference - Building Enclosure Science \& Technology, 2010.

[153] E. Ilter, A. Tavil, O.C. Celik, Full-scale performance testing and evaluation of unitized curtain walls, J. Facade Des. Eng. 3 (1) (2015) 39-47.

[154] B.S. Kaskel, M.J. Scheffler, I.R. Chin, "Critical review of curtain wall mockup testing for water penetration", Water leakage through building facades, ASTM Int. (1998), https://doi.org/10.1520/STP12106S.

[155] Y. Yu, T. Liu, B. Yang, Q. Zhang, "Wind-induced response of an L-shaped cable supported glass curtain wall", Shock and Vibration, published online, https:// www.hindawi.com/journals/sv/aip/4163045/, 2017

[156] P. Di, C.-L. Yu, "Safety analysis of point supported glass curtain wall panels", Proceedings of ICSEEE 2015 - 4th International Conference on Sustainable Energy and Environmental Engineering, 2015.

[157] L.J. Aurelius, A.W. Rofail, "Inter-Tenancy Wall Design for Tall Buildings with Operable Facades", Proceedings of 12AWES - Australian Wind Engineering Society Workshop, Queenstown, New Zealand, 2-3 February, 2006.

[158] W.-J. Lou, H. Li, K.-Z. Wei, Y. Chen, H.-L. Li, Wind tunnel test study on wind pressure distribution on double-skin facades of high-rise buildings with typical shapes, J. Harbin Inst. Technol. (2008). 02.

[159] I.S. Mitsos, S.D. Guest, S. Nhamoinesu, M. Overend, "Investigation of a doublelayer tensegrity glazing system", Proceedings of IASS-APCS Annual Symposium, Seoul, South Korea, 21-24 May, 2012.

[160] N.E. Meinen, R.D.J.M. Steenbergen, C.P.W. Geurts, C.A. van Bentum, Probabilistic Assessment of Wind-Loaded Façade Elements, Springer, Cham, 2017, pp. 345-364. 